\title{
Changes in calcification of coccoliths under stable atmospheric $\mathrm{CO}_{2}$
}

\author{
C. Berger ${ }^{1}$, K. J. S. Meier ${ }^{1}$, H. Kinkel ${ }^{2}$, and K.-H. Baumann ${ }^{3}$ \\ ${ }^{1}$ Christian-Albrechts-Universität zu Kiel, Institute of Geosciences, Ludewig-Meyn-Str. 10, 24118 Kiel, Germany \\ ${ }^{2}$ University of Southern Denmark, Campusvej 55, 5230 Odense, Denmark \\ ${ }^{3}$ Universität Bremen, Department of Geosciences, 28334 Bremen, Germany \\ Correspondence to: C. Berger (cbauke@ gpi.uni-kiel.de)
}

Received: 13 May 2013 - Published in Biogeosciences Discuss.: 13 June 2013

Revised: 21 November 2013 - Accepted: 15 January 2014 - Published: 20 February 2014

\begin{abstract}
The response of coccolithophore calcification to ocean acidification has been studied in culture experiments as well as in present and past oceans. The response, however, is different between species and strains, and for the relatively small carbonate chemistry changes observed in natural environments, a uniform response of the entire coccolithophore community has not been documented so far. Moreover, previous palaeo-studies basically focus on changes in coccolith weight due to increasing $\mathrm{CO}_{2}$ and the resulting changes in the carbonate system, and only few studies focus on the influence of other environmental factors. In order to untangle changes in coccolithophore calcification due to environmental factors such as temperature and/or productivity from changes caused by increasing $p \mathrm{CO}_{2}$ and decreasing carbonate ion concentration, we here present a study on coccolith calcification from the Holocene North Atlantic Ocean. The pre-industrial Holocene, with its predominantly stable atmospheric $\mathrm{CO}_{2}$, provides the conditions for such a comprehensive analysis. For an analysis on changes in major components of Holocene coccolithophores under natural conditions, the family Noelaerhabdaceae was selected, which constitutes the main part of the assemblage in the North Atlantic.

Records of average coccolith weights from three Holocene sediment cores along a north-south transect in the North Atlantic were analysed. During the Holocene, mean weight (and therefore calcification) of Noelaerhabdaceae (Emiliania huxleyi and Gephyrocapsa) coccoliths decreased at the Azores (Geofar KF 16) from around 7 to $6 \mathrm{pg}$, but increased at the Rockall Plateau (ODP site 980) from around 6 to $8 \mathrm{pg}$, and at the Vøring Plateau (MD08-3192) from 7 to $10 \mathrm{pg}$. The amplitude of average weight variability is within the range of glacial-interglacial changes that were interpreted to be an effect of decreasing carbonate ion concentration. By com-
\end{abstract}

parison with SEM assemblage counts, we show that weight changes are not only partly due to variations in the coccolithophore assemblage but also an effect of a change in calcification and/or morphotype variability within single species. Our results indicate that there is no single key factor responsible for the observed changes in coccolith weight. A major increase in coccolith weight occurs during a slight decrease in carbonate ion concentration in the late Holocene at the Rockall Plateau and Vøring Plateau. Here, more favourable productivity conditions apparently lead to an increase in coccolith weight, either due to the capability of coccolithophore species, especially $E$. huxleyi, to adapt to decreasing carbonate ion concentration or due to a shift towards heavier calcifying morphotypes.

\section{Introduction}

With the increasing anthropogenic influence on the carbon cycle by $\mathrm{CO}_{2}$ emissions into the atmosphere over the past $250 \mathrm{yr}$, seawater carbonate chemistry changed due to the uptake of atmospheric $\mathrm{CO}_{2}$ into the ocean (Doney et al., 2009). One result of the uptake is a decrease in seawater $\mathrm{pH}$, a process known as ocean acidification (Feely et al., 2004; Raven et al., 2005; IPCC, 2007). The impact of ocean acidification on calcifying organisms, e.g. corals, molluscs and calcifying plankton, is one of the most actively followed marine research topics to have been studied in recent years (e.g. Gattuso et al., 1998; Riebesell et al., 2000; Fabry et al., 2008). A special focus lies on organisms that interact with the global carbon cycle. Among other calcifying plankton groups, particularly interesting are coccolithophores, which are one of the main producers of calcite in the oceans. Their small 
calcite scales, the coccoliths, form a large part of the carbonate flux from the surface to the deep ocean (Westbroek et al., 1993). As they can act as ballast in sinking organic aggregates, coccoliths enhance the vertical mass transfer of organic carbon and therefore have an influence on the biological carbon pump (Klaas and Archer, 2002; Ploug et al., 2008). Thus, variations in coccolith mass affect the sinking velocity of the aggregates and consequently the organic carbon export to depth (Beaufort et al., 2007; Ziveri et al., 2007; Zondervan et al., 2001). The term "calcification" has different definitions in biology and geology. Biologists define calcification as the rate of $\mathrm{CaCO}_{3}$ production, i.e. the amount of $\mathrm{CaCO}_{3}$ produced over time. On the other hand, palaeontologists distinguish between weakly and well-calcified coccoliths based on morphological criteria (Young et al., 2003; Read et al., 2013). We here use the term "coccolith calcification" in a palaeontological sense, i.e. referring to the grade of calcification of coccoliths. A relation between coccolith calcification rate and the grade of coccolithophore calcification (expressed as coccolith weight) has been demonstrated (Bach et al., 2012).

It is known that changing seawater carbonate chemistry influences coccolithophore calcification (Riebesell et al., 2000; Beaufort et al., 2011). Previous culture studies on different coccolithophore taxa reveal both species-specific and strain-specific optimum curve responses to changing carbonate chemistry (Langer et al., 2006; Krug et al., 2011). However, the most frequent response in recently conducted experiments is a decrease in coccolithophore calcification under future $p \mathrm{CO}_{2}$ levels (Zondervan et al., 2002; De Bodt et al., 2010; Bach et al., 2012). A recently conducted study on sediment samples in different ocean basins presented a correlation between decreasing coccolith weight and declining carbonate ion concentration during the $\mathrm{CO}_{2}$ increase of the last deglaciation (Beaufort et al., 2011). Interestingly, in the same study, the authors observed a morphotype of the extant species Emiliania huxleyi in waters of the Patagonian Shelf and the Chilean upwelling that is able to calcify heavily in waters characterised by low carbonate ion concentrations. These findings were recently supported by the findings of Smith et al. (2012), who detected a seasonal dominance of a heavily calcified $E$. huxleyi morphotype in the Bay of Biscay under elevated $\mathrm{CO}_{2}$ conditions. As calcification in coccolithophore species and even strains shows an optimum response with respect to various carbonate chemistry parameters (Krug et al., 2011; Bach et al., 2011), these results may indicate that this morphotype has its calcification optimum at a relatively low $\mathrm{pH}$. Apart from seawater carbonate chemistry, other factors also have an effect on coccolithophore calcification. Environmental factors such as temperature (Grelaud et al., 2009), coccolithophore productivity (Beaufort et al., 2007; Flores et al., 2012), salinity (Bollmann and Herrle, 2007), nutrient concentration and irradiance (Zondervan, 2007) are also suggested to have an influence on coccolith weight and size. However, according to Beaufort et al. (2011) these factors play a minor role for coccolith calcification when the carbonate chemistry changes notably. Thus it can be expected during times of rather stable atmospheric $\mathrm{CO}_{2}$ that the influence of other environmental factors will be more prominent than the carbonate chemistry of the sea water. The scale of variability in coccolith calcification in an environment with only minor changes in the carbonate system is still unknown, as are the consequences for the mean calcite mass of a coccolithophore community. For reliable predictions of future coccolith calcification under elevated $\mathrm{CO}_{2}$ conditions predicted for the end of the century (Raven et al., 2005; IPCC, 2007), it is necessary to study them in a natural environment with relatively constant $\mathrm{CO}_{2}$ conditions. The probably relatively minor changes in the carbonate system over the last $10000 \mathrm{yr}$ allow for testing the influence of environmental conditions (temperature, coccolithophore productivity) on coccolith calcification. Studies on palaeo-light conditions or nutrient concentrations are not possible due to missing geological proxies. In our study, we focus on the coccolithophore family Noelaerhabdaceae as it dominates the coccolithophore assemblage in the Holocene North Atlantic and represents up to $84 \%$ of the assemblage (e.g. Andruleit, 1995; Andruleit and Baumann, 1998; Schwab et al., 2012). The variability of single Noelaerhabdaceae coccolith weight was measured in three Holocene sediment cores along a north-south transect in the North Atlantic. The diverse trends and gradients of temperature, carbonate ion concentration and coccolithophore productivity in the three studied cores allow for insights to be gained into which of the factors are reflected in coccolith weight and therefore in their calcification.

\section{Material and methods}

\subsection{Material}

Holocene sediment samples from three sediment cores from the North Atlantic areas were analysed. Piston core GEOFAR KF 16 was retrieved southwest of the Azores islands $\left(37^{\circ} 99.90^{\prime} \mathrm{N}, 31^{\circ} 12.83^{\prime} \mathrm{W}\right)$ from a water depth of $3050 \mathrm{~m}$ (GEOFAR cruise; Richter, 1998). Additionally, a surface sediment sample from the same location (boxcore GEOFAR KG 14) was analysed. ODP site $980\left(55^{\circ} 12.90^{\prime} \mathrm{N}\right.$, $14^{\circ} 14.20^{\prime} \mathrm{W} ; 2179 \mathrm{~m}$ water depth) is located in the eastern North Atlantic at the Rockall Plateau and was taken during ODP leg 162 (Jansen et al., 1996). The Calypso square core MD08-3192 was taken at $66^{\circ} 55.86^{\prime} \mathrm{N}, 7^{\circ} 33.92^{\prime} \mathrm{E}$ in $1010 \mathrm{~m}$ water depth in the eastern Norwegian Sea (Kissel et al., 2009) (Fig. 1).

\subsection{Age models}

The age model for core GEOFAR KF 16 was published by Schwab et al. (2012). The Holocene part of the age model of this core is based on accelerator mass spectrometer (AMS) 


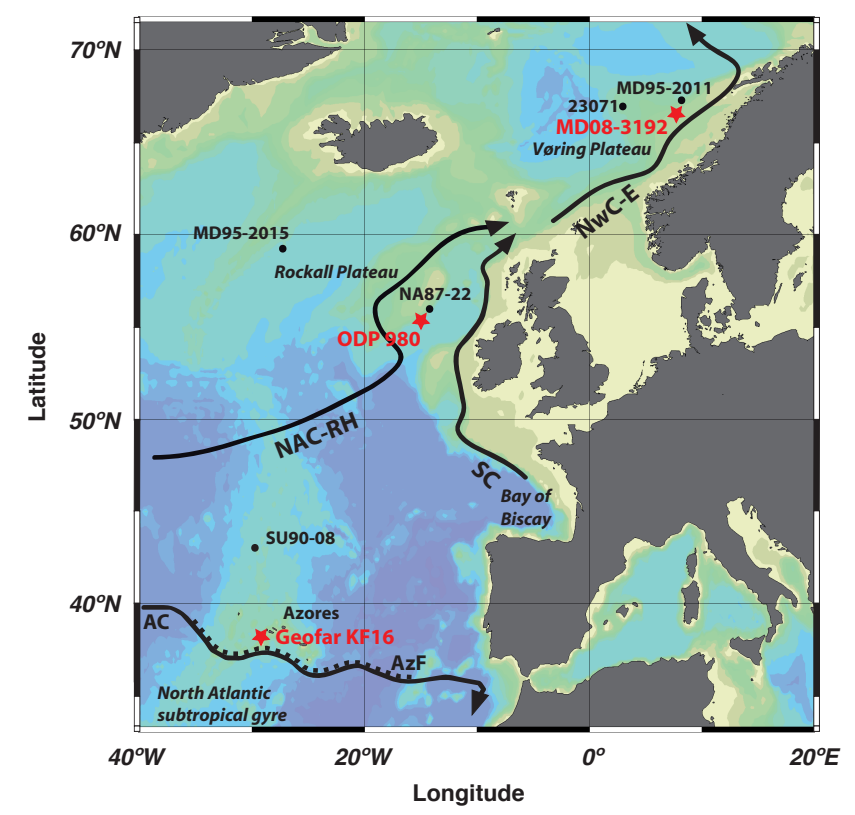

Fig. 1. Core position and main oceanographic features. Red stars mark the location of the studied sediment cores; black dots mark the position of other locations providing data for calculations of the carbonate system or coccolith counts discussed in the text. Black arrows show major ocean surface currents: North Atlantic Current Rockall-Hatton branch (NAC-RH), Slope Current (SC), eastern branch of the Norwegian Current (NwC-E), and Azores Current (AC), with the corresponding Azores Front (AzF) figured as a black dashed line. The map was designed with the ODV software by R. Schlitzer (Ocean Data View software, 2010, http://odv.awi.de/.

data of planktonic foraminifera (Globigerina bulloides, Globigerinoides ruber). In addition, an alkenone SST record and a planktonic oxygen isotope record were correlated with the NGRIP oxygen isotope record. The age model for ODP site 980 relies on AMS measurements of the benthic foraminifera Cibicidoides wuellerstorfi (Oppo et al., 2006). We established an age model for MD08-3192 by graphically tuning red-green colour-scan data to the nearby core MD952011 using the software package Analyseries (Paillard et al., 1996). Significant peaks in the colour-scan data at the end of the Younger Dryas and during the middle and late Holocene were used as tie points. The age model of core MD95-2011 is based on AMS ${ }^{14} \mathrm{C}$ dates of the foraminifera Neogloboquadrina pachyderma (Risebrobakken et al., 2003).

\subsection{Methods}

\subsubsection{Sample preparation (smear slides, SEM), imaging and SYRACO weight measurements}

A few milligrams of sediment were taken with a toothpick, mixed with a drop of water on a glass microscope slide and smeared homogeneously on the slide. After drying quickly on a hot plate, the sediment was fixed with 3-4 drops of the resin EUKITT and a cover slip. For scanning the smear slides a polarised light microscope (Leica DM6000B) with 1000× magnification was used. The microscope was equipped with a SPOT Insight black and white camera. Between 200 and 400 pictures of every sample were taken. The light of the microscope bulb was continuously controlled to avoid a decrease in light intensity over time. Every 10 smear slides, 200 images of two control slides were taken and the brightness was checked with the program ImageJ and compared with the previous results. In addition, a weekly control with the highest possible light conditions of the microscope was conducted. Both methods revealed brightness changes of less than $2 \%$ and are therefore negligible.

The automated recognition software for coccolithophores SYRACO (Beaufort and Dollfus, 2004) was used to identify and measure coccoliths. The software identifies and classifies coccoliths in the image files and returns output files containing coccoliths of a single species. In the output files, coccolith length and the grey level of every component pixel were measured. The sum of grey levels of a coccolith image was used to estimate coccolith weight. The brightness of coccolith calcite depends on its thickness, which can be expressed in an equation. After calibration to a known calcite standard (method after Beaufort et al., 2005, with a calcite particle size of $1-2 \mu \mathrm{m}$ ) the summation of grey level of every single coccolith can be converted with an equation (weight $=$ grey level $\times 0.0016$ ) into the estimated weight of the coccolith in picogram. Depending on coccolith content in the sediment sample and the preparation of the smear slide, roughly between 100 and 3500 Noelaerhabdaceae coccoliths were measured in each sample, in total 89160 single coccoliths (see supplementary information). Error bars with $95 \%$ confidence intervals are shown in Fig. 2 and 5-10 to assess the statistical significance of each data point. For a more detailed description of SYRACO, see Beaufort et al. (2004, 2005).

For scanning electron microscope (SEM, CamScan CS44) studies, three samples from each core representing the early, middle and late Holocene were prepared following standard protocols (Andruleit, 1996). The first 50 coccoliths of E. huxleyi and G. muellerae showing the distal shield were classified concerning size and calcification state.

\subsubsection{Carbonate chemistry, salinity, temperature and coccolithophore productivity}

Alkenone sea surface temperature (SST) data at the Azores are available from Schwab et al. (2012). At the Rockall Plateau, no published SST data were available for ODP site 980; instead alkenone temperature data from site MD952015 (Marchal et al., 2002) were used as an indication. The SST data of MD95-2015 were compared to SST data from ODP site 980 (Holtvoeth, unpublished), which confirm the general trend (with a difference of around $3{ }^{\circ} \mathrm{C}$ upwards) but slightly differ after $4 \mathrm{ka}$ BP. Furthermore, no SST data were 


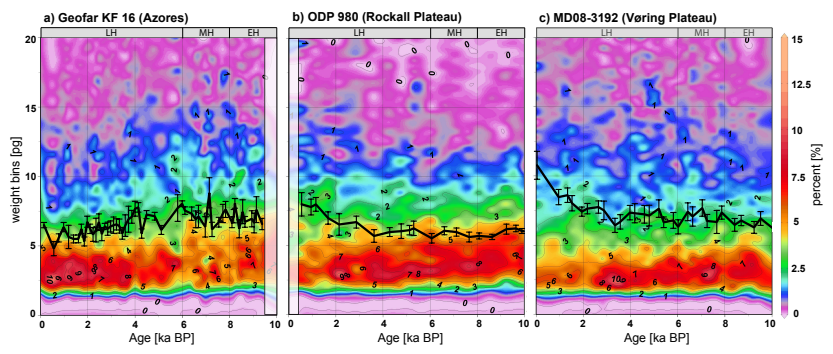

Fig. 2. (a) Azores, core Geofar KF 16; (b) Rockall Plateau, ODP site 980; and (c) Vøring Plateau, core MD08-3192. Abundance of Noelaerhabdaceae coccoliths within weight bins (colours) and Noelaerhabdaceae mean coccolith weight (black line). Abundance of Noelaerhabdaceae coccoliths within weight bins (colours) and Noelaerhabdaceae mean coccolith weight (black line). For the weight bins the data set has been divided into classes (bins) with a step of $0.4 \mathrm{pg}$ : each bin contains the frequency of data points in percent of each sample from the Holocene data set. Error bars indicate $95 \%$ confidence intervals of the mean weight. Abbreviations: early Holocene (EH), middle Holocene (MH), late Holocene (LH)

obtainable for core MD08-3192, alkenone temperature from nearby site MD95-2011 were used (Calvo et al., 2002).

Coccolith accumulation rate has been successfully used to trace palaeoproductivity dynamics (Lototskaya et al., 1998; Stolz and Baumann, 2010; Schwab et al., 2012), which reflect the nutrient content at the surface ocean as, for example, in eutrophic conditions coccolithophore productivity is enhanced (Baumann et al., 2005). Coccolith accumulation rates are available for the Azores from Schwab et al. (2012). Rockall Plateau coccolith concentrations are based on SEM counts and were calculated into coccolith accumulation rates by using the bulk density (Jansen et al., 2005) and sedimentation rate of ODP site 980 using the equation of Van Kreveld et al. (1996). Vøring Plateau coccolith concentrations were provided by Giraudeau (MD95-2011, unpublished) and calculated into coccolith accumulation rates by using the sedimentation rate and bulk density of sediment core MD952011 (Bassinot and Labeyrie, 1996). Carbonate ion concentrations at the coring sites were calculated with the program CO2Sys (Lewis and Wallace, 1998). Salinity, temperature, total alkalinity and $p \mathrm{CO}_{2}$ were used as input parameters. The parameterisation is interlinked as total alkalinity was derived from SST and salinity using the equation of Lee et al. (2006). Salinity was reconstructed from $\Delta \delta^{18} \mathrm{O}$ using the equation of Duplessy et al. (1991). Taylor Dome ice core data were used for atmospheric $\mathrm{CO}_{2}$ (Indermühle et al., 1999). For the calculation of $\Delta \delta^{18} \mathrm{O}, \Delta \delta^{18} \mathrm{O}_{\text {seawater }}$ was derived to correct the

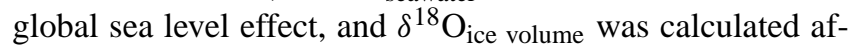
ter Waelbroeck et al. (2002). At the Rockall Plateau, salinity estimates from the adjacent core NA87-22 (Duplessy et al., 2005 ) were used. At the Azores and the Vøring Plateau salinity was calculated from $\Delta \delta^{18} \mathrm{O}$, which is based on the data
Geofar KF 16 from Schwab et al. (2012) and MD95-2011 from Risebrobakken et al. (2003).

\section{Palaeoceanographic changes during the Holocene}

Sediment core Geofar KF 16 is positioned southwest of the Azores Islands, at the northern rim of the subtropical gyre (Richter, 1998). The northeastern boundary of the subtropical gyre is defined by the Azores Current System with the corresponding Azores Front (Klein and Siedler, 1989; Rogerson et al., 2004). The Azores Front separates two different productivity regimes: low primary production in the subtropical gyre in the south, and nutrient-rich conditions in the north (Schwab et al., 2012). At the coring site, enhanced productivity during the early Holocene is followed by a shift to modern oligotrophic conditions around $6 \mathrm{ka}$ BP. The productivity changes due to a northward shift of the Azores Front in the late Holocene (Schwab et al., 2012). SST at the coring site is around $20^{\circ} \mathrm{C}$ in the early Holocene, decreases to $17.8^{\circ} \mathrm{C}$ at $8.2 \mathrm{ka} \mathrm{BP}$ and stabilises after $8 \mathrm{ka}$ BP to modern conditions of $18.5-19.5^{\circ} \mathrm{C}$.

ODP site 980 is located in the North Atlantic at the eastern edge of Rockall Plateau, in the high accumulation area of the Feni Drift, which is deposited along the northwestern flank of the Rockall Trough (Jansen et al., 1996). The Rockall Plateau is mainly influenced by West North Atlantic Water of the North Atlantic Current and its local northerly flowing Rockall-Hatton Branch, carrying warm and salty water. Eastward of the Rockall Plateau, the warmer, more saline and less stratified Slope Current flows into the Rockall Trough (Hansen and Østerhus, 2000; Pollard et al., 2004). This current belongs to East North Atlantic Water and origins in the Bay of Biscay (Read, 2001). Between 7 and 5.4 ka BP, a reorganisation of surface circulation patterns in the northeastern North Atlantic occurred due to decreasing summer insolation and the end of meltwater influence. The reorganisation resulted in a weaker North Atlantic current and a stronger influence of the Slope Current after 5-6 ka BP (Solignac et al., 2008). These regional changes are reflected in an increase of alkenone SST at ODP site 980 between 3.5 and $2 \mathrm{ka}$ and a subsequent decrease (J. Holtvoeth, personal communication, 2013) and explain the opposing SST trend to site MD952015 after $3.5 \mathrm{ka}$ BP. The coccolithophore productivity at ODP site 980 fluctuates highly over the entire Holocene, with highest rates in the early and late Holocene.

Core MD08-3192, taken from the Vøring Plateau in the eastern Norwegian Sea, is influenced by the Norwegian Atlantic Current, an extension of the North Atlantic Current (Andersson et al., 2010). Most of this water inflow originates from the slope current, carrying warm and saline water into higher latitudes (Blindheim and Østerhus, 2005). During the early Holocene, the North Atlantic current increased in strength (Birks and Koç, 2002); warmest sea surface conditions during the Holocene occurred in the early Holocene 
until approximately $6 \mathrm{ka}$ BP (Berner et al., 2011). During the middle and late Holocene, SST decreased to presentday conditions, synchronous to decreasing summer insolation (Calvo et al., 2002). Coccolithophore productivity rates at the Vøring Plateau increased during the entire Holocene and reached a maximum peak between 3 and $4 \mathrm{ka}$ BP (Giraudeau et al., 2010).

\section{Coccolithophore family Noelaerhabdaceae}

In our examined sites the coccolithophore family Noelaerhabdaceae includes Emiliania huxleyi and Gephyrocapsa. Both coccolithophore taxa in our study can be classified into different morphotypes and species. The Holocene Gephyrocapsa complex consists of a number of different species, with frequencies dependent on the location. Gephyrocapsa muellerae is highly abundant in the North Atlantic, in a preferred temperature range of $12-18^{\circ} \mathrm{C}$ (Giraudeau et al., 2010), and often used as a cold water indicator (Weaver and Pujol, 1988).

The small species Gephyrocapsa ericsonii and Gephyrocapsa ornata have a preference for high nutrient contents and less saline surface water conditions (Boeckel et al., 2006), but are less abundant in our examined sites, especially in the two northernmost. Gephyrocapsa oceanica favours high nutrient concentrations and warmer waters (Kleijne et al., 1989; Bollmann et al., 1997). It is a minor taxa in our sites due to its distribution in lower latitudes (Ziveri et al., 2004).

The cosmopolitan coccolithophore species $E$. huxleyi has an extensive genetic and morphologic diversity with diverse environmental tolerances (Medlin et al., 1996; Young, 2003; Read et al., 2013) and dominates the assemblage in our examined sites. In the Holocene North Atlantic, E. huxleyi can be separated into different types with regard to coccolith size and weight. Coccoliths $<4 \mu \mathrm{m}$ are highly abundant in Holocene samples, while coccoliths $>4 \mu \mathrm{m}$, which serve as a cold water indicator, are more common in glacial sediments and decrease during the deglaciation (Termination I) (Colmenero-Hidalgo et al., 2002; Flores et al., 2010). Recently, Smith et al. (2012) reported on increasing abundance of a heavily calcified E. huxleyi morphotype in the North Atlantic (Bay of Biscay) during winter, when $\mathrm{pH}$ and $\mathrm{CaCO}_{3}$ saturation are lowest. These findings support the results of Beaufort et al. (2011), who observed a highly calcified $E$. huxleyi morphotype, adapted to waters with low $\mathrm{pH}$. There are also reports of weakly calcified $E$. huxleyi cells in naturally low pH oceanic regimes (e.g. Beaufort et al., 2011; Poulton et al., 2011).

Regarding the mean coccolith weight of Noelaerhabdaceae, the different response of coccolithophore species and their morphotypes to environmental factors should be taken into account. A major abundance shift of one species or morphotypes can have an influence on the mean weight of Noelaerhabdaceae coccoliths.

\section{Results}

\subsection{Holocene Noelaerhabdaceae weight trends}

Mean Noelaerhabdaceae coccolith weight in sediment core Geofar KF 16 (Azores) shows a two-part trend during the Holocene (Fig. 2a). Characterised by significant oscillations over the entire Holocene, the mean coccolith weight record fluctuates around $7 \mathrm{pg}$ in the early and middle Holocene until $6 \mathrm{ka} \mathrm{BP}$, and subsequently decreases to values of less than $6 \mathrm{pg}$ in the late Holocene. The same change can be observed in the relative abundance of Noelaerhabdaceae coccolith weight classes (Fig. 2a). During the early and middle Holocene a relatively broad weight range reaches high relative abundance. In the late Holocene the range narrows and a distinct maximum between 2 and $3 \mathrm{pg}$ is observed.

At Rockall Plateau, mean Noelaerhabdaceae coccolith weight fluctuates around $6 \mathrm{pg}$ during the early and middle Holocene, as well as the beginning of the late Holocene, followed by an increase to $8 \mathrm{pg}$ after $3.5 \mathrm{ka} \mathrm{BP}$ in the late Holocene (Fig. 2b). The relative abundance of Noelaerhabdaceae coccolith weight classes shows a maximum of light coccoliths between 3 and $5 \mathrm{pg}$ in the early and middle Holocene (Fig. 2b). In the late Holocene the maximum of light coccoliths is less pronounced and narrows to 2.5 and $4 \mathrm{pg}$, paralleled by an increase in the abundance of heavier weight classes. From 1 ka BP onwards, the maximum of light coccoliths further flattens, and simultaneously the weight classes extend to heavier values.

At the Vøring Plateau, mean Noelaerhabdaceae coccolith weight increases with a range of fluctuations during the entire Holocene from around 7 to more than $10 \mathrm{pg}$. The weight increase is rather slight until $3 \mathrm{ka}$ BP and notably stronger afterwards (Fig. 2c). The relative abundance of Noelaerhabdaceae weight classes shows a narrowing maximum of light coccoliths from 2 to $4.5 \mathrm{pg}$ in the early Holocene to $2-3.5 \mathrm{pg}$ in the late Holocene (Fig. 2c). From 1.2 ka BP onwards, the maximum of light coccoliths is less pronounced. The relative abundance of heavier weight classes is high over the entire Holocene.

\subsection{Carbonate ion concentration}

Despite the rather stable atmospheric $\mathrm{CO}_{2}$ conditions, the reconstructed carbonate ion concentration in all studied cores decreases over the Holocene (Fig. 3). At the Azores carbonate ion concentration is highest. It decreases by about $30 \mu \mathrm{mol} \mathrm{kg}{ }^{-1} \mathrm{SW}$ over the Holocene, from more than 260 to $230 \mu \mathrm{mol} \mathrm{kg}^{-1} \mathrm{SW}$. At the Rockall Plateau the carbonate ion concentration is strikingly lower and decreases by $15 \mu \mathrm{mol} \mathrm{kg}{ }^{-1} \mathrm{SW}$ from 200 to $185 \mu \mathrm{mol} \mathrm{kg} \mathrm{kW}^{-1} \mathrm{SW}$. The carbonate ion concentration at the Vøring Plateau represents the highest decrease of $45 \mu \mathrm{mol} \mathrm{kg}{ }^{-1} \mathrm{SW}$ from 225 to $180 \mu \mathrm{mol} \mathrm{kg}^{-1} \mathrm{SW}$ from the early to the late 


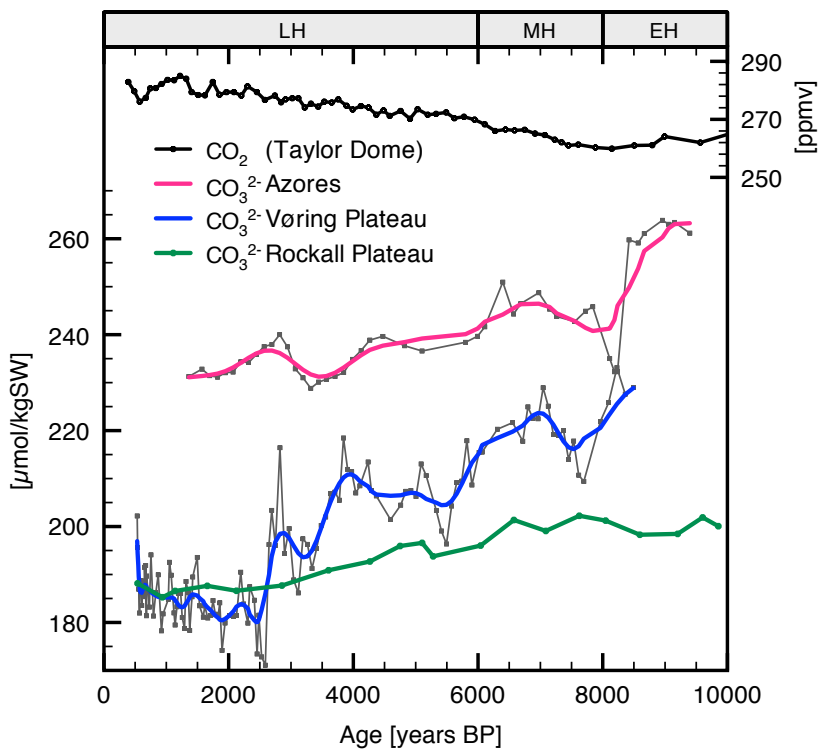

Fig. 3. Holocene carbon dioxide concentration from Taylor Dome ice core data (Indermühle et al., 1999; black line) and Holocene carbonate ion concentration of Azores (red line), Rockall Plateau (green line) and Vøring Plateau (blue line). Bold lines are smoothed (by factor a 4), and grey thin lines represent original data.

Holocene, with a slight increase from $2.5 \mathrm{ka}$ BP onwards to $190 \mu \mathrm{mol} \mathrm{kg}{ }^{-1} \mathrm{SW}$.

\section{Discussion}

\subsection{Comparison with previous studies}

Coccolithophore calcification can be reflected in the exocytosis rate, in the size of coccoliths and in the weight per coccolith (Bach et al., 2012). A correlation between calcification rates and coccolith weight has been observed in E. huxleyi, expressed in a simultaneous change in coccolith weight and exocytosis rate (Bach et al., 2013). Single coccolith weights are therefore a potential indicator for calcification rates. However, it is not known as to whether this relationship, which was established on clonal cultures, holds true for an entire assemblage. In similar experiments, Müller et al. (2012) saw no correlation between the coccolith mass and the rate of calcification or particulate inorganic carbon (PIC) production. It should be mentioned that the coccolith weights in the results of Bach et al. (2012) were measured with SYRACO, whereas the coccolith mass in the results of Müller et al. (2012) was calculated by using the coccolith volume that was determined via Coulter Multisizer ${ }^{\mathrm{TM}}$. Previous studies have also shown a correlation between calcification rates and coccolith weight (Beaufort et al., 2007), and coccolith weight has been demonstrated to be a useful indicator for changes in ocean carbonate chemistry (Beaufort et al., 2011). However, there seems to be no universal relationship

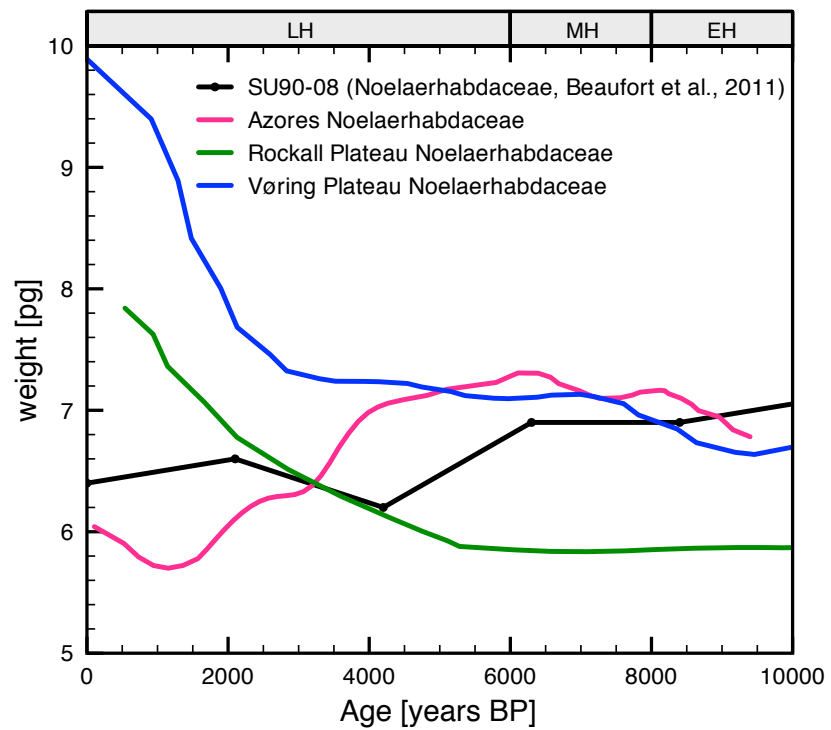

Fig. 4. Noelaerhabdaceae coccolith weights from core SU90-08 (Beaufort et al., 2011, black line) in comparison to Noelaerhabdaceae smoothed mean weight record from the Azores (red line), Rockall Plateau (green line) and Vøring Plateau (blue line).

between calcification rates and coccolith weight, which has to be kept in mind when interpreting coccolith weight data.

The decreasing coccolith weight trend of Noelaerhabdaceae observed at the Azores is in line with results from previous studies (Beaufort et al., 2011); see Fig. 4. In one site of the data set of Beaufort et al. (2011, Supplement), the authors studied a core near the Azores (SU90-08) covering the Holocene and recognised a decrease in coccolith mass of the family Noelaerhabdaceae of around $0.5 \mathrm{pg}$. Our own data from the Azores (Geofar KF 16) confirm this trend and show a decrease of about $1 \mathrm{pg}$ for Noelaerhabdaceae coccolith mean weight (Fig. 4). It should be mentioned that the Noelaerhabdaceae weight of Beaufort et al. (2011) is represented by five data points and is therefore able to reflect the mean trend but not the short-term changes of coccolith weight. Therefore the mean coccolith weights of sediment core SU90-08 and Geofar KF 16 are not exactly the same but reflect the same decreasing trend.

The studied sites from Rockall and Vøring Plateau show some different developments of Noelaerhabdaceae coccolith weights (Fig. 4). At both sites the weight and the general variation in weight is rather comparable in the early and middle Holocene and increases during the late Holocene.

According to Beaufort et al. (2011) decreasing carbonate ion concentration affects coccolithophore calcification and explains the decrease in coccolith weight in their results. In our studied sites and in the results of Beaufort et al. (2011) the carbonate ion concentration decreases between 10 and $45 \mu \mathrm{mol} \mathrm{kg}{ }^{-1}$ of sea water (Fig. 3). Despite the decreasing trend in all sites, the coccolith weight reacts differently and leads to the assumption that other factors have a stronger 


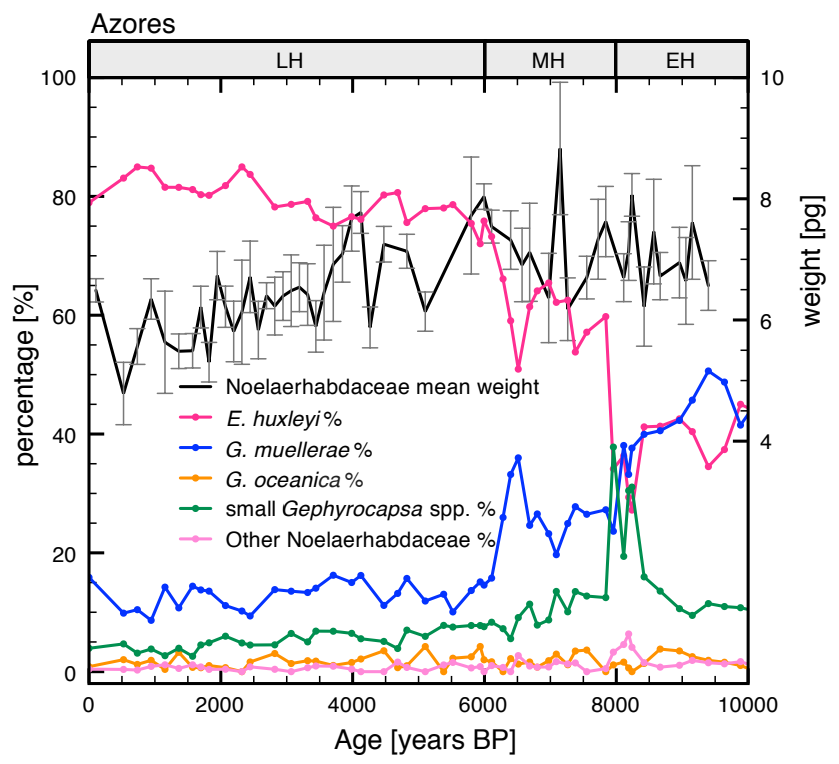

Fig. 5. Relative abundance of Noelaerhabdaceae species at the Azores from sediment core Geofar KF 16 over the Holocene (Schwab et al., 2012): E. huxleyi (red line), G. muellerae (blue line), G. oceanica (orange line), small Gephyrocapsa (green line) and other Noelaerhabdaceae (light-red line) in comparison to the Noelaerhabdaceae mean coccolith weight (black line).

influence on mean Noelaerhabdaceae coccolith weight in our studied sites of the Holocene North Atlantic. Possible factors that have an influence on the mean weight are other environmental factors such as the sea surface temperature and coccolithophore productivity or changes within the assemblage of Noelaerhabdaceae.

\subsection{The influence of assemblage shifts within the Noelaerhabdaceae}

Weight changes of Noelaerhabdaceae due to assemblage shifts could have resulted from either changes in the relative abundance of differently calcifying species and/or their individual morphotypes within Noelaerhabdaceae, or even changes in the weight of species and/or their morphotypes within the Noelaerhabdaceae.

To improve the identification and quantification of our results, we compared the Noelaerhabdaceae mean weights to previously published SEM counts of our studied cores or nearby cores. According to SEM counts of Schwab et al. (2012), the family Noelaerhabdaceae at the Azores consists of coccoliths from the species E. huxleyi, G. muellerae, few G. ericsonii and G. ornata and a very small number of G. oceanica (Fig. 5). At the Rockall Plateau, Noelaerhabdaceae counts from ODP site 980 include primarily E. huxleyi and G. muellerae and few G. oceanica and G. ericsonii (Fig. 6). At the Vøring Plateau, no SEM counts for the entire Holocene were available for MD08-3192; therefore a comparison to coccolith counts of Andruleit (1995) from a nearby

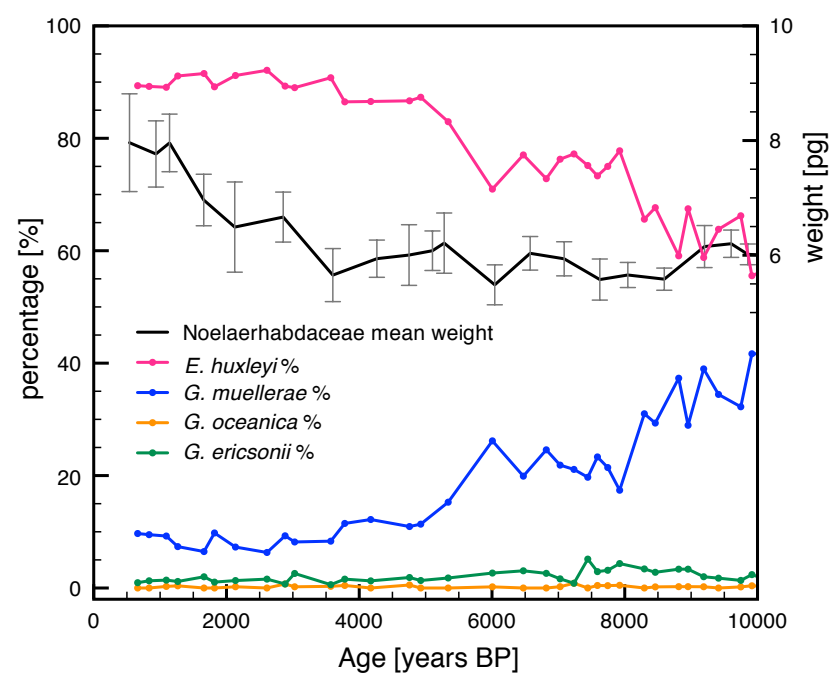

Fig. 6. Relative abundance of Noelaerhabdaceae species at Rockall Plateau from ODP site 980 over the Holocene (Baumann, previously unpublished): E. huxleyi (red line), G. muellerae (blue line), G. oceanica (orange line) and G. ericsonii (green line) in comparison to the Noelaerhabdaceae mean coccolith weight (black line).

core (GIK 23071) is used as an indication (Fig. 7). At this site the family Noelaerhabdaceae consists of E. huxleyi and G. muellerae; other coccolithophores of this family are not mentioned, and in all probability their number is less than $1 \%$ and not worth considering.

In all three SEM counts of Noelaerhabdaceae, the assemblage considerably changes over the Holocene. In general, related to the main part of the assemblage, the relative abundance of the lighter species E. huxleyi increases by around $30 \%$, while the heavier G. muellerae decreases similarly. Interestingly, these changes are not reflected in the mean weight of the studied sites, not even the strong decrease of G. muellerae at the Vøring Plateau between 7 and $8 \mathrm{ka}$ BP. Therefore it seems very likely that the species themselves change their weight. This could be caused by changes in the weight of E. huxleyi or G. muellerae or both. Another explanation is a shift in the abundance of, for example, a heavily calcifying morphotype of $E$. huxleyi or G. muellerae or both.

For verification we examined SEM samples from characteristic intervals of all cores. In all samples, the highest morphotype variability with regard to coccolith calcification was found in $E$. huxleyi. The most common morphotype was $E$. huxleyi type A, displaying varying degrees of calcification (Fig. 8). Coccoliths of E. huxleyi type A overcalcified increased over the Holocene, and were most abundant in the late Holocene samples from the Vøring Plateau (18 of 50 coccoliths) and Rockall Plateau (12 of 50 coccoliths). At the Azores, they were only present in the late Holocene (4 of 50 coccoliths). Coccolith calcification is less variable in $G$. muellerae, where only slight differences in the bridge were found. 


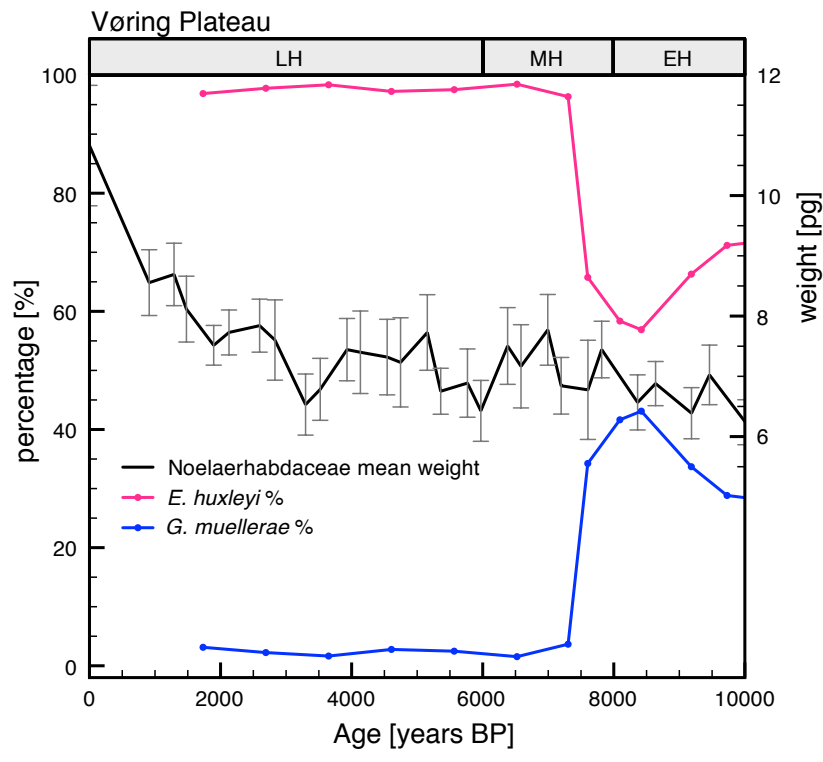

Fig. 7. Relative abundance of Noelaerhabdaceae species at Vøring Plateau from sediment core GIK 23071 over the Holocene (Andruleit, 1995): E. huxleyi (red line), G. muellerae (blue line), in comparison to the Noelaerhabdaceae mean coccolith weight (black line).

At the Vøring Plateau and the Rockall Plateau it is very likely that the increasing abundance of overcalcified $E$. huxleyi morphotypes increases the mean Noelaerhabdaceae weight. The central area and the slits between the T elements in this E. huxleyi morphotype are closing (Figs. 5, 6, 8), which makes it easily detectable, and presumably a lot heavier than a normal calcified morphotype. However, the change in calcification of E. huxleyi coccoliths alone would probably not be sufficient to explain the observed weight increase. A stronger calcification in G. muellerae is therefore likely, but would be more difficult to detect, as the distal shield is already composed of directly adjacent elements. A decrease in thickness would therefore be difficult to see in distal view. Potentially, the observed slight difference in the size of the bridge could also contribute to the weight increase. Our results do not support the high number of $G$. muellerae reported in light-microscopic counts of Giraudeau et al. (2010), which show an increase of G. muellerae at the Vøring Plateau after $2 \mathrm{ka}$ BP. In our SEM counts we detected a very low abundance of around $1 \%$ G. muellerae.

\subsection{Environmental factors}

Based on our results, the individual response of single coccolithophore species and most likely their morphotypes is primarily responsible for changes in Noelaerhabdaceae weight. Hence, it is necessary to consider the factors that have an influence on species weight or changes in the abundance of their morphotypes. It is known that different coccolithophore species or morphotypes are adapted to individ-

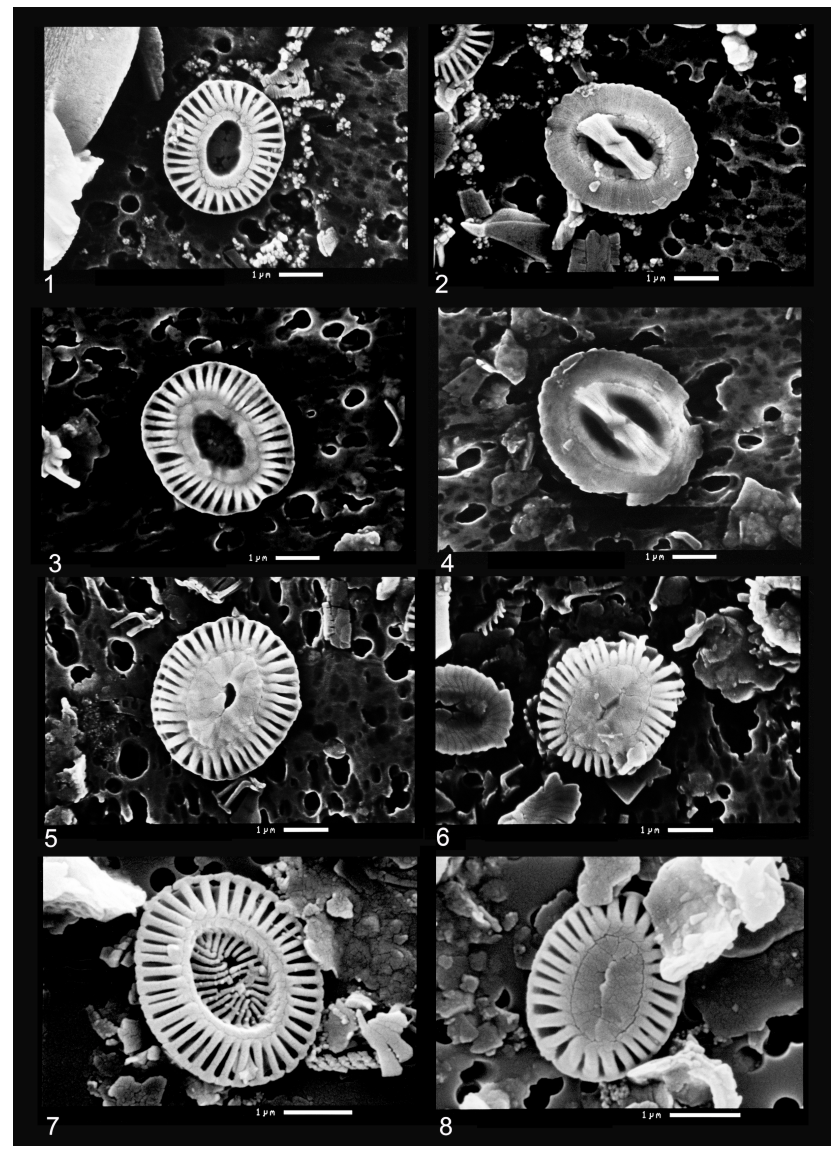

Fig. 8. SEM images of Noelaerhabdaceae coccoliths. (1) E. huxleyi (Azores), (2) G. muellerae (Azores), (3) E. huxleyi (Rockall Plateau), (4) G. muellerae (Rockall Plateau), (5) overcalcified E. huxleyi (Rockall Plateau, (6) overcalcified E. huxleyi (Rockall Plateau), (7) E. huxleyi (Vøring Plateau) and (8) overcalcified E. huxleyi (Vøring Plateau). All scale bars are $1 \mu \mathrm{m}$.

ual environmental conditions (Bollmann, 1997; Henderiks et al., 2012). This might explain the implication of Beaufort et al. (2011) that coccolith weight in the North Atlantic and South Indian Ocean differ from tropical settings, especially during the Last Glacial Maximum, where coccolith weight displays a broad weight range but is not in line with the trend of coccolith weight from the tropical stack. Therefore it is not as simple as proposed to consider one main factor, such as the carbonate system, as the key factor for changes in coccolith weight, especially not for the North Atlantic, which deviates from the tropical or global trend. In the data set of Beaufort et al. (2011), temperature, productivity and salinity are also correlated to coccolith calcification, but statistically less significant than $\mathrm{CO}_{2}$ or carbonate ion concentration. This already indicates that other factors than carbonate ion concentration are important for coccolith calcification.

It should be mentioned that our selected sites are located in areas affected by seasonal variations in productivity, temperature and $p \mathrm{CO}_{2}$ (Nilsen, 2003; Rios et al., 2005; Tans 
and Conway, 2005; Schwab et al., 2012). As coccolithophore productivity generally also follows a seasonal pattern (Smith et al., 2012; Triantaphyllou et al., 2010; Meier et al., 2014), it is likely that the mean coccolithophore weight is mainly influenced by the specific environmental conditions during the main coccolithophore productivity period. Changes in the timing of the productivity period or seasonality changes in the environment over longer timescales could therefore potentially lead to shifts in the mean coccolith weight trend, which are not accounted for in the reconstructed environmental parameters.

\subsubsection{Temperature}

In our examined sites, SST decreases over the entire Holocene by less than $2{ }^{\circ} \mathrm{C}$ (Figs. 9c, 10c, 11c) and is unlikely to have a strong influence on Noelaerhabdaceae mean coccolith weight. Previous studies present indications for an influence on changes in SST on the abundance of coccolithophore species and their morphotypes or on their calcification, but with considerably higher temperature gradients (Hagino et al., 2005; Bach et al., 2012; Henderiks et al., 2012). In addition, studies on correlations between temperature and calcification rates of E. huxleyi showed different results (Langer et al., 2007; de Bodt et al., 2010). Beaufort et al. (2007) concluded that there is no global relationship between SST and the degree of E. huxleyi calcification. The influence of SST on E. huxleyi morphotypes is even more confusing due to its high morphologic and genetic diversity with different temperature tolerances (Young et al., 2003; Hagino et al., 2011), and it seems that the same morphotype can react differently. A heavily calcified E. huxleyi morphotype is reported to increase in abundance when SST is higher (Beaufort and Heussner, 2001; Grelaud et al., 2009), contrary to the results of Smith et al. (2012), where this morphotype increases during winter in the Bay of Biscay. For Gephyrocapsa, only little is known about changes in calcification rate induced by temperature variability. The distribution of Gephyrocapsa species in the Holocene correlates with environmental gradients (Bollmann, 1997); for example, $G$. muellerae occurs in moderate productive cool surface waters (Winter et al., 1994) and is thus often used as a cold water indicator (Weaver and Pujol, 1988), whereas G. oceanica has an affinity to warm and nutrient-rich waters (Kleijne et al., 1989; Giraudeau et al., 1993; Ziveri and Thunell, 2000) and is therefore reported to be abundant in temperate and tropical waters as well as equatorial and upwelling areas (Okada and McIntyre, 1979; Bollmann, 1997; Ziveri et al., 2004). Due to the different response of species and morphotypes to SST, it is difficult to make a general statement for the coccolithophore family Noelaerhabdaceae regarding changes in SST. The slight decrease in temperature in our sites over the Holocene is unlikely to influence the calcification of coccoliths. More likely is the influence of morphotypes, which are adapted to different temperature conditions and therefore oc- cur in different abundances in our sites. As detected by Flores et al. (2010), the abundance of the E. huxleyi cold water type with coccoliths $>4 \mu \mathrm{m}$ increases with higher latitudes and reaches $1-5 \%$ at Vøring Plateau. The opposite trend is found in the distribution of G. oceanica of our studied sites. The abundance record decreases from less than $5 \%$ at the Azores to around $1 \%$ at Rockall Plateau and is probably absent at Vøring Plateau. Both coccolithophores could have an influence on the mean Noelaerhabdaceae coccolith weight, but the low amount of 1-5\% might be too small to have significant effects on the average weight.

\subsubsection{Salinity}

Reconstructed palaeo-salinity changes at our coring sites are rather small at the Rockall Plateau (35.9-36.2), slightly higher at the Azores (35.9-37.4) and show high fluctuations at the Vøring Plateau (34.6-38.2). Despite some studies showing correlations between size and weight of $E$. huxleyi in plankton and culture studies with salinity (Bollmann et al., 2009; Fielding et al., 2009), there is no correlation between Noelaerhabdaceae mean coccolith weight in our results and the reconstructed palaeo-salinity (not shown).

\subsubsection{Carbonate ion concentration}

Different factors of the oceans' carbonate system are discussed to affect calcification rates of coccolithophores such as $\mathrm{pH}$ levels, carbonate ion or bicarbonate ion concentration (Bach et al., 2012). During the Holocene the atmospheric $\mathrm{CO}_{2}$ concentration changes only to a minor extent, and consequently the reconstructed carbonate system of the ocean as well (Zeebe, 2012). As we focused more on environmental factors than on the oceans carbonate system, we decided to show the parameter of the carbonate system which attracted attention in the study of Beaufort et al. (2011) in order to compare our results with the large data set of the authors.

Despite the minor changes of the atmospheric $\mathrm{CO}_{2}$ concentration in the Holocene, the $\mathrm{CO}_{2}$ solubility in the ocean changes geographically and seasonally due to the dependence on parameters such as SST, salinity, alkalinity and productivity (Feely et al., 2001; Zeebe and Wolf-Gladrow, 2001). At present day, the average $\mathrm{CO}_{2}$ uptake of the ocean is smaller in the Azores region than at the Rockall or Vøring Plateau (see map of Takahashi et al., 2002). Our reconstructions of the Holocene carbonate system show a regional difference; for example, the decrease of the carbonate ion concentration over the Holocene at the Vøring Plateau is stronger than at the Azores or the Rockall Plateau.

The influence of the biological productivity, which strengthens the biological pump and leads to a decrease in $\mathrm{CO}_{2}$ of the surface ocean and thus to changes in the oceans' carbonate system (Sigman and Haug, 2003), is not included in the reconstructions. It is therefore likely that the rising productivity at the Vøring Plateau enhanced the biological pump 


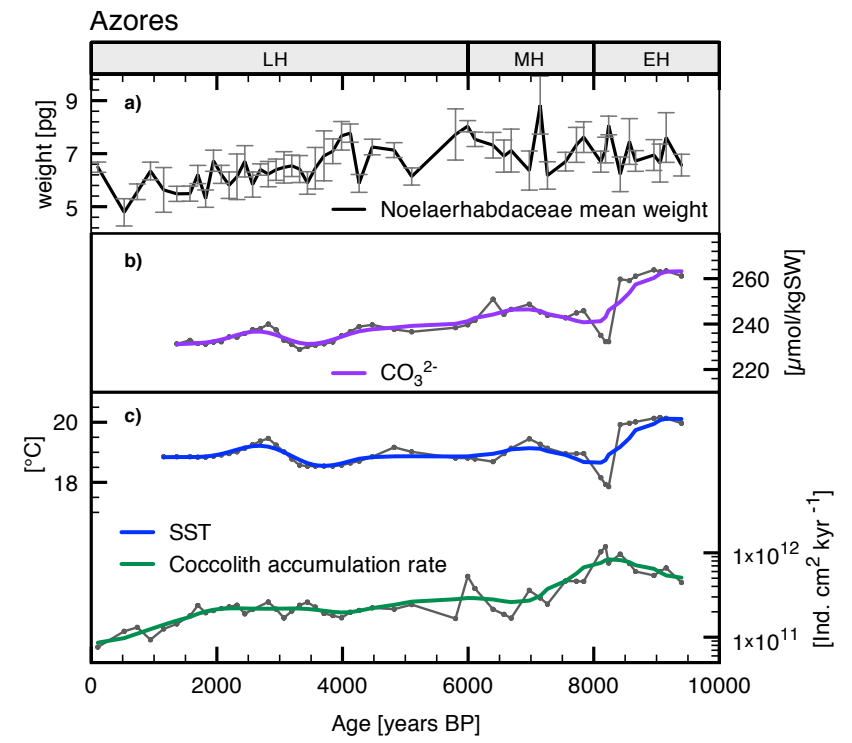

Fig. 9. Azores, core Geofar KF 16. (a) Noelaerhabdaceae mean coccolith weight (black line); error bars indicate $95 \%$ confidence intervals of the mean weight. (b) Carbonate ion concentration (purple line) (c) SST (Schwab et al., 2012; blue line) and coccolith accumulation rate (Schwab et al., 2012; green line). Bold lines are smoothed (by factor of 4), and grey thin lines represent original data.

and led to a decrease in $\mathrm{CO}_{2}$ of the surface ocean. It is possible that the decrease in carbonate ion concentration is weaker than in our reconstructions. Conversely, the decreasing productivity at the Azores could lead to a stronger decrease in carbonate ion concentration than reconstructed. But despite these uncertainties, the Holocene changes in the oceans carbonate system still are much smaller in comparison to, for example, the glacial-interglacial variability of the carbonate system.

The decrease in carbonate ion concentration of around $30 \mu \mathrm{mol} \mathrm{kg}^{-1}$ in our results at the Azores might have an influence on coccolith mean weight (Fig. 9b), but here the carbonate ion concentration presents the highest values of all three studied sites; therefore the basic conditions for coccolithophores should be more favourable than at the Rockall or Vøring Plateau. At the Rockall Plateau the decreasing trend in carbonate ion concentration of around $10 \mu \mathrm{mol} \mathrm{kg}^{-1}$ sea water over the Holocene might be too small to have a large influence on coccolith calcification (Fig. 10b). At the Vøring Plateau, the decrease in Holocene carbonate ion concentration is relatively prominent (about $45 \mu \mathrm{mol}$, Fig. 11b) and is even stronger than at the Azores, but the increasing coccolith weight does not confirm the negative influence of carbonate ion concentration on the weight. Therefore there is no uniform trend of Noelaerhabdaceae weight at the three different sites, and a general influence of decreasing carbonate ion concentration in the range of 10-45 $\mu \mathrm{mol}$ on coccolith weight cannot be observed. This indicates that the carbonate system

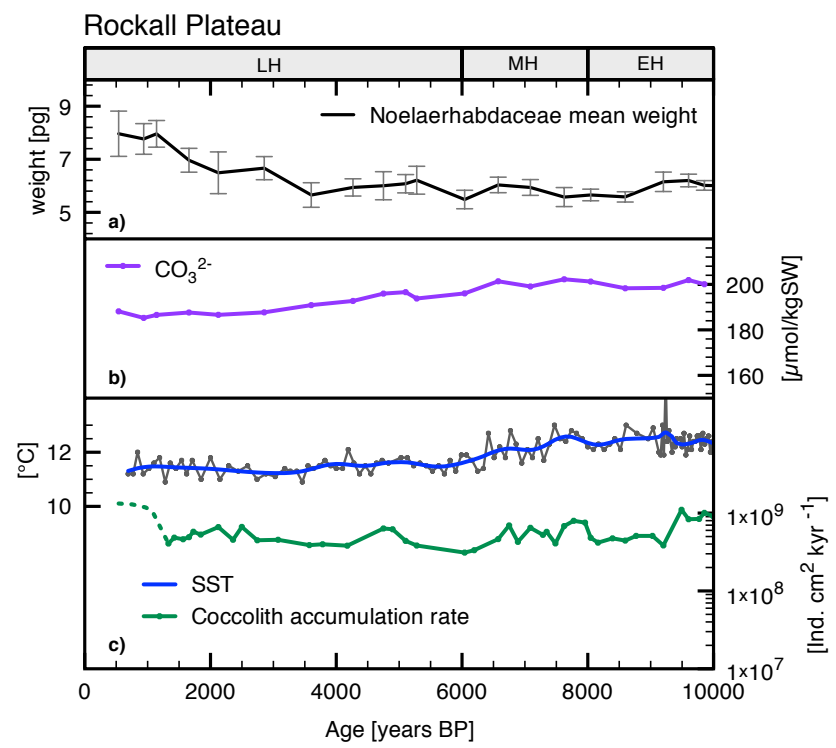

Fig. 10. Rockall Plateau, ODP site 980. (a) Noelaerhabdaceae mean coccolith weight (black line). Error bars indicate $95 \%$ confidence intervals of the mean weight. (b) Carbonate ion concentration (purple line) (c) SST (Marchal et al., 2002; blue line) and coccolith accumulation rate (green line). Bold lines are smoothed (by factor of 4), and grey thin lines represent original data.

cannot be the main factor having influence on the mean coccolith weight in the Holocene North Atlantic.

\subsubsection{Coccolithophore productivity}

The coccolithophore productivity decreases northwards in our examined sites in absolute numbers. The relative trends are different between the sites over the Holocene (Figs. 9c, $10 \mathrm{c}, 11 \mathrm{c})$. At the Azores, coccolithophore productivity is highest. Beginning with the onset of a northward shift of the Azores Front and the following oligotrophic conditions after $6 \mathrm{ka}$ BP (Schwab et al., 2012), the mean coccolith weight starts decreasing, suggesting a possible coupling between coccolithophore productivity and coccolith calcification. Similarly, at the Vøring Plateau, where absolute coccolithophore productivity is 2 to 3 orders of magnitude lower, an overall increase in coccolithophore productivity over the entire Holocene is paralleled by the increasing Noelaerhabdaceae coccolith weight. At the Rockall Plateau the coccolithophore productivity is on the same level as at the Vøring Plateau, but relatively stable. Here, only a slight increase in coccolith productivity is observed during the late Holocene, when coccolith weight increases markedly, and coccolithophore productivity peaks are only slightly reflected in the mean weight. This may be caused by undersampling of the mean coccolith weight data, which could exclude shortterm fluctuations from being detected.

Previous studies have shown the influence of enhanced coccolithophore productivity on coccolith weight. 
The weight of E. huxleyi increased during blooms and accordingly during times with high coccolithophore production (Beaufort et al., 2007). In addition Engel et al. (2005) observed an increase in E. huxleyi coccolith weight by 25 to $50 \%$ during blooms in mesocosm experiments after adding nutrients. However, in the presence of different morphotypes, coccolith weight can be controlled by morphotype dominance, which may vary within different parts of a bloom and over the course of the bloom (Poulton et al., 2011). Therefore, productivity plays a major role in coccolith calcification and is probably rather prominent in our study because $\mathrm{CO}_{2}$ variability is low during the Holocene. Considering the environmental factors in all three sites, the main trends of temperature and carbonate ion concentration are rather similar. The only distinct difference in the studied environmental factors is the coccolithophore productivity, which seems to have an influence on mean Noelaerhabdaceae coccolith weight. As the absolute values in coccolithophore productivity are extremely different between the Azores and the two northern sites, it is unlikely that productivity as such is responsible for the observed changes in coccolith weight. A more likely explanation would be abundance changes of morphotypes within the Noelaerhabdaceae, which might be also caused by different nutrient or primary productivity regimes. This may be due to oceanographic features such as the position of the subtropical gyre and the frontal system at the Azores (Schwab et al., 2012), or the re-organisation of the surface circulation patterns in the northern North Atlantic with a stronger influence of the Slope Current after 5-6 ka BP (Solignac et al., 2008; J. Holtvoeth, personal communication, 2013) at the Rockall Plateau and Vøring Plateau.

At the Vøring Plateau, Noelaerhabdaceae mean coccolith weight is controlled by two species: E. huxleyi and $G$. muellerae. Interestingly, and as previously mentioned, the shift in the relative abundance of the species between 7 and $8 \mathrm{ka} \mathrm{BP}$ is neither reflected in the mean weight nor the increase in weight in the late Holocene. This leads to the assumption that either changing calcification of the species or abundance shifts of morphotypes are the responsible mechanism for the observed signal.

Coccolithophore calcification is affected by both nitrogen and phosphorous limitation in laboratory experiments on single strains (Müller et al., 2008, 2012; Satoh et al., 2009; Kayano and Shiraiwa, 2009). While coccolith volume and weight increases, the number of coccoliths may be reduced, resulting in a net decrease in calcification. The same effect may occur also under nutrient-replete conditions under elevated $p \mathrm{CO}_{2}$ (Müller et al., 2012). These laboratory results are, however, difficult to translate into natural assemblages. Seasonal coccolith weight records from the Mediterranean Sea indicate that coccolith weight is relatively small during times of nutrient depletion, but increases during the main production period (Triantaphyllou et al., 2010; Meier et al., 2014). As we demonstrate an increase of coccolithophore weight during times of enhanced coccolith accumulation, we

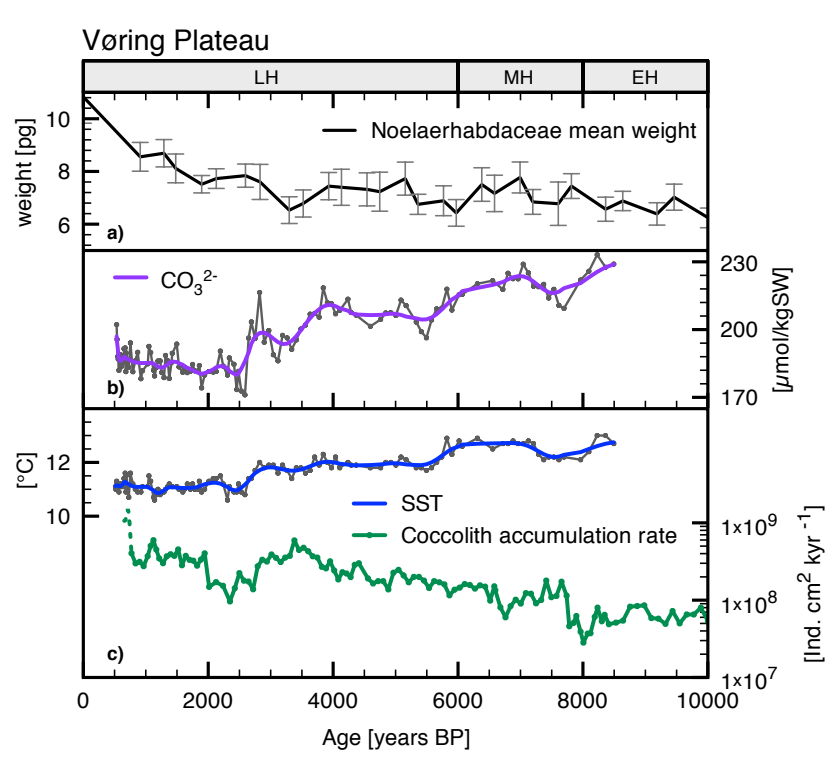

Fig. 11. Vøring Plateau, core MD08-3192. (a) Noelaerhabdaceae mean coccolith weight (black line). Error bars indicate $95 \%$ confidence intervals of the mean weight. (b) Carbonate ion concentration (purple line) and (c) SST (Calvo et al., 2002; blue line) and coccolith accumulation rate (Giraudeau, unpublished; green line). Bold lines are smoothed (by factor of 4), and grey thin lines represent original data.

assume that the effect of coccolithophore production is reflected in the coccolith weight signal. Therefore, abundance shifts of species and morphotypes are likely to have a larger effect than calcification changes due to nutrient depletion.

Compared to G. muellerae, E. huxleyi is a tough competitor and able to adapt more quickly to environmental changes (Okada and Wells, 1997; Schwab et al., 2012). A recently conducted long-term study by Lohbeck et al. (2012) revealed an adaptation of $E$. huxleyi calcification to enhanced $\mathrm{CO}_{2}$ due to genotypic selection as well as mutations within the population. The presence of a morphotype of E. huxleyi that is able to calcify heavily in waters characterised by low carbonate ion concentrations supports this theory (Beaufort et al., 2011; Smith et al., 2012). Interestingly, in the findings of Beaufort et al. (2011), this morphotype appears in relatively cold coastal or frontal upwelling waters with enhanced productivity. Therefore it is not unlikely to assume that the heavily calcifying $E$. huxleyi morphotype in the uppermost sediment sample at the Vøring Plateau is an adaptation to decreasing carbonate ion concentration, while other environmental factors such as productivity are rather favourable. In contrast, at the Azores the decreasing productivity conditions are likely to impair the conditions for coccolithophore species or morphotypes. This might be a tentative indication that, on a global scale, a part of the coccolith weight decrease expected to occur due to ocean acidification in the future could be compensated for by increased productivity of heavily calcifying coccolithophore species or morpho- 
Table 1. Summary of Noelaerhabdaceae weight trends and controlling factors.

\begin{tabular}{|c|c|c|c|c|c|}
\hline Site & $\begin{array}{l}\text { Noelaerhabdaceae } \\
\text { mean weight }\end{array}$ & $\mathrm{CO}_{3}^{2-}$ & SST & $\begin{array}{l}\text { Coccolith } \\
\text { accumulation }\end{array}$ & $\begin{array}{l}\text { E. huxleyi } \\
\text { overcalcified }\end{array}$ \\
\hline $\begin{array}{l}\text { Geofar KF } 16 \\
\text { ODP } 980 \\
\text { MD08-3192 }\end{array}$ & $\begin{array}{l}\text { slight decrease } \\
\text { moderate increase } \\
\text { strong increase }\end{array}$ & $\begin{array}{l}\text { slight decrease } \\
\text { slight decrease } \\
\text { slight decrease }\end{array}$ & $\begin{array}{l}\text { warm, slight decrease } \\
\text { temperate, slight decrease } \\
\text { temperate, slight decrease }\end{array}$ & $\begin{array}{l}\text { very high, slight decrease } \\
\text { high, relatively stable } \\
\text { low, slight increase }\end{array}$ & $\begin{array}{l}\text { slight increase } \\
\text { strong increase } \\
\text { strong increase }\end{array}$ \\
\hline
\end{tabular}

types (e.g. growing in frontal or upwelling regimes) adapted to calcify heavily at low carbonate ion concentrations. The same is especially true for other heavily calcifying coccolithophore species, such as Coccolithus pelagicus or Calcidiscus leptoporus that may reach considerable abundance in parts of the oceans and have a large influence on the total coccolithophore carbonate production. Therefore, future studies should focus on assemblage and morphotype response to carbonate system changes.

\section{Conclusions}

Different processes lead to the observed strong variability in mean coccolith weight of the dominant coccolithophore family Noelaerhabdaceae during rather stable $\mathrm{CO}_{2}$ conditions of the pre-industrial Holocene in the North Atlantic (Table 1). The recently debated negative influence of decreasing carbonate ion concentration on coccolithophore calcification could not be detected for a small decrease of 10 to $45 \mu \mathrm{mol} \mathrm{kg}{ }^{-1} \mathrm{SW}$. Our results show weight changes during the Holocene of the same amplitude as previously reported for the $\mathrm{CO}_{2}$ increase of the last glacial to interglacial change, but with opposing trends in different regions. Variability in Holocene Noelaerhabdaceae coccolith weight in a natural system of the North Atlantic is unlikely driven by the carbonate system as a main reason. We show that in the absence of strong $\mathrm{CO}_{2}$ variability in the North Atlantic, coccolithophore productivity has a substantial influence on Noelaerhabdaceae coccolith weight. Favourable environmental conditions such as high coccolithophore productivity lead to increasing weight, either due to increasing calcification or an abundance shift to heavily calcifying morphotypes, such as the increase of an overcalcified type of E. huxleyi, even during times of decreasing carbonate ion concentration of $45 \mu \mathrm{mol} \mathrm{kg}{ }^{-1} \mathrm{SW}$ over the Holocene. Differences in nutrient or productivity settings between the sites are likely influencing the response of Noelaerhabdaceae coccolith weight. The high natural variability of coccolith weight during the Holocene raises the question as to whether future changes in the carbonate system of the oceans will have a positive or negative effect on coccolithophore calcification.

\section{Supplementary material related to this article is available online at http://www.biogeosciences.net/11/929/ 2014/bg-11-929-2014-supplement.pdf.}

Acknowledgements. The authors thank J. Giraudeau for providing the coccolithophore data of site MD95-2011, J. Holtvoeth for discussions on temperature and surface currents of the Rockall Plateau, and K. Kleiven for providing the sediment samples of site MD08-3192. B. Dannielou and IFREMER are acknowledged for providing samples of core GEOFAR KF 16. B. Mohr from the SEM laboratory at the Institute of Geosciences is thanked for her support during scanning electron microscopy and image processing. T. Oberließen and S. Häuser are thanked for their help in preparing the samples and images. Funds for this study were provided by the Federal Ministry of Education and Research (Bundesministerium für Bildung und Forschung, 03F0608A) in the framework of the Biological Impacts of Ocean Acidification (BIOACID) project. We also thank the anonymous reviewers and the handling editor for the constructive and helpful comments.

Edited by: D. Gillikin

\section{References}

Andersson, C., Pausata, F. S. R., Jansen, E., Risebrobakken, B., and Telford, R. J.: Holocene trends in the foraminifer record from the Norwegian Sea and the North Atlantic Ocean, Clim. Past, 6, 179-193, doi:10.5194/cp-6-179-2010, 2010.

Andruleit, H.: Coccolithophoriden im Europäischen Nordmeer: Sedimentation und Akkumulation; sowie ihre Entwicklung während der letzten 15000 Jahre, Berichte aus dem Sonderforschungsbereich, 313, Christian-Albrechts-Universität, Kiel, 59, 1995.

Andruleit, H.: A filtration technique for quantitative studies of coccoliths, Micropaleontology, 42, 403-406, 1996.

Andruleit, H. A. and Baumann, K.-H.: History of the Last Deglaciation and Holocene in the Nordic Seas as revealed by coccolithophore assemblages, Mar. Micropaleontol., 35, 179-201, 1998.

Bach, L. T., Bauke, C., Meier, K. J. S., Riebesell, U., and Schulz, K. G.: Influence of changing carbonate chemistry on morphology and weight of coccoliths formed by Emiliania huxleyi, Biogeosciences, 9, 3449-3463, doi:10.5194/bg-9-3449-2012, 2012.

Bassinot, F. C. and Labeyrie, L. D.: Shipboard Scientific Party (1996): IMAGES MD101 Brest- Marseille 29/05/95-11/07/95 A coring cruise of the R/V Marion Dufresne in the North Atlantic 
Ocean and Norwegian Sea, Les rapports de campagnes à la mer, Institut Français pour la Recherche et la Technologie Polaires, Technopole de Brest-lroise, BP75-29280 Plouzane, Francee de Brest-lroise, BP75-29280 Plouzane, France, 96, 217 pp., 1996.

Baumann, K.-H., Andruleit, H., Böckel, B., Geisen, M. and Kinkel, H.: The significance of extant coccolithophores as indicators of ocean water masses, surface water temperature, and palaeoproductivity: a review, Paläontologische Zeitschrift, 79, 93-112, 2005.

Beaufort, L.: Weight estimates of coccoliths using the optical properties (birefringence) of calcite, Micropaleontology, 51, 289297, 2005.

Beaufort, L. and Heussner, S.: Seasonal dynamics of calcareous nannoplankton on a West European continental margin: the Bay of Biscay, Mar. Micropaleontol., 43, 27-55, 2001.

Beaufort, L. and Dollfus, D.: Automatic recognition of coccoliths by dynamical neural networks, Mar. Micropaleontol., 51, 57-73, doi:10.1016/j.marmicro.2003.09.003, 2004.

Beaufort, L., Probert, I., and Buchet, N.: Effects of acidification and primary production on coccolith weight: implications for carbonate transfer from the surface to the deep ocean, Geochem. Geophy. Geosy., 8, Q08011, doi:10.1029/2006GC001493, 2007.

Beaufort, L., Probert, I., de Garidel-Thoron, T., Bendif, E. M., RuizPino, D., Metzl, N., Goyet, C., Buchet, N., Coupel, P., Grelaud, M., Rost, B., Rickaby, R. E. M., and de Vargas, C.: Sensitivity of coccolithophores to carbonate chemistry and ocean acidification, Nature, 476, 80-83, doi:10.1038/nature10295, 2011.

Berner, K., Koç, N., Godtliebsen, F., and Divine, D.: Holocene climate variability of the Nor-wegian Atlantic Current during high and low solar insolation forcing, Paleoceanography, 26, PA2220, doi:10.1029/2010PA002002, 2011.

Birks, C. and Koç, N.: A high-resolution diatom record of lateQuaternary sea-surface tempera- tures and oceanographic conditions from the eastern Norwegian Sea, Boreas, 31, 323-344, 2002 .

Blindheim, J. and Østerhus, S.: The Nordic Seas, main oceanographic features, in: The Nordic Seas, An Integrated Perspective, edited by: Drange, H., Dokken, T., Furevik, T., Gerdes, R., and Berger, W., Geophysical Monograph Series 158, American Geophysical Union, Washington DC, 11-38, 2005.

Boeckel, B., Baumann, K.-H., Henrich, R., and Kinkel, H.: Coccolith distribution patterns in South Atlantic and southern Ocean surface sediments in relation to environmental gradients, DeepSea Res. Pt. I, 53, 1073-1099, doi:10.1016/j.dsr.2005.11.006, 2006.

Bollmann, J.: Morphology and biogeography of Gephyrocapsa coccoliths in Holocene sediments, Mar. Micropaleontol., 29, 319350, 1997.

Bollmann, J. and Herrle, J.: Morphological variation of Emiliania huxleyi and sea surface salinity, Earth Planet. Sc. Lett., 255, 273288, doi:10.1016/j.eps1.2006.12.029, 2007.

Bollmann, J., Herrle, J. O., Cortés, M. Y., Fielding, S. R.: The effect of sea water salinity on the morphology of Emiliania huxleyi in plankton and sediment samples, Earth Planet. Sc. Lett., 284, 320-328, doi:10.1016/j.eps1.2009.05.003, 2009.

Calvo, E., Grimalt, J., and Jansen, E.: High resolution U37K sea surface temperature recon- struction in the Norwegian Sea during the Holocene, Quaternary Sci. Rev., 21, 1385-1394, 2002.
Colmenero-Hidalgo, E., Flores, J. A., and Sierro, F. J.: Biometry of Emiliania huxleyi and its biostratigraphic significance in the eastern North Atlantic Ocean and western Mediterranean Sea in the last 20000 years, Mar. Micropaleontol., 46, 247-263, 2002.

De Bodt, C., Van Oostende, N., Harlay, J., Sabbe, K., and Chou, L.: Individual and interacting effects of $p \mathrm{CO}_{2}$ and temperature on Emiliania huxleyi calcification: study of the calcite pro- duction, the coccolith morphology and the coccosphere size, Biogeosciences, 7, 1401-1412, doi:10.5194/bg-7-1401-2010, 2010.

Doney, S., Fabry, V., Feely, R., and Kleypas, J.: Ocean acidification: the other $\mathrm{CO}_{2}$ problem, Annual Review of Marine Science, 1, 169-192, 2009.

Duplessy, J. C., Labeyrie, L., Juillet-Leclerc, A., Maitre, F., Duprat, J., and Sarnthein, M.: Surface salinity reconstruction of the North Atlantic Ocean during the last glacial maximum, Oceanol. Acta, 14, 311-324, 1991.

Duplessy, J. C., Cortijo, E., and Kallel, N.: Marine records of Holocene climatic variations, C. R. Geosci., 337, 87-95, doi:10.1016/j.crte.2004.08.007, 2005.

Engel, A., Zondervan, I., Aerts, K., Beaufort, L., Benthien, A., Chou, L., Delille, B., Gattuso, J. P., Harlay, J., Heemann, C., Hoffmann, L., Jacquet, S., Nejstgaard, J., Pizay, M. D., RochelleNewall, E., Schneider, U., Terbrueggen, A., Riebesell, U.: Testing the direct effect of $\mathrm{CO} 2$ concentration on a bloom of the coccolithophorid Emiliania huxleyi in mesocosm experiments, Limnol. Oceanogr., 50, 493-507, 2005.

Fabry, V. J., Seibel, B. A., Feely, R. A., and Orr, J. C.: Impacts of ocean acidification on marine fauna and ecosystem processes, ICES J. Mar. Sci., 65, 414-432, doi:10.1093/icesjms/fsn048, 2008.

Feely, R. A., Sabine, C. L., Kitack, L., Berelson, W., Kleypas, J., Fabry, V. J., and Millero, F. J.: Impact of anthropogenic $\mathrm{CO}_{2}$ on the $\mathrm{CaCO}_{3}$ system in the ocean, Science, 305, 362-366, 2004

Fielding, S. R., Herrle, J. O., Bollmann, J., Worden, R. H., and Montagnes, D. J. S.: Assessing the application of Emiliania huxleyi coccolith morphology as a sea-surface salinity proxy, Limnol. Oceanogr., 54, 5, 1475-1480, 2009.

Flores, J. A., Colmenero-Hidalgo, E., Mejía-Molina, A. E., Baumann, K.-H., Henderiks, J., Lars- son, K., Prabhu, C. N., Sierro, F. J., and Rodrigues, T.: Distribution of large Emiliania huxleyi in the Central and Northeast Atlantic as a tracer of surface ocean dynamics during the last 25000 years, Mar. Micropaleontol., 76, 53-66, doi:10.1016/j.marmicro.2010.05.001, 2010.

Flores, J.-A., Filippelli, G. M., Sierro, F. J., and Latimer, J.: The "white ocean" hypothesis: a late pleistocene southern ocean governed by coccolithophores and driven by phosphorus, Front. Microbiol., 3, 233, doi:10.3389/fmicb.2012.00233, 2012.

Gattuso, J., Frankignoulle, M., Bourge, I., Romaine, S., and Buddemeier, R.: Effect of calcium carbonate saturation of seawater on coral calcification, Global Planet. Change, 18, 37-46, 1998.

Giraudeau, J., Monteiro, P., and Nikodemus, K.: Distribution and malformation of living coccolithophores in the northern Benguela upwelling system off Namibia, Mar. Micropaleontology, 22, 93-110, 1993

Giraudeau, J., Grelaud, M., Solignac, S., Andrews, J., Moros, M., and Jansen, E.: Millennial-scale variability in Atlantic water advection to the Nordic Seas derived from Holocene coccolith concentration records, Quaternary Sci. Rev., 29, 1276-1287, doi:10.1016/j.quascirev.2010.02.014, 2010. 
Grelaud, M., Schimmelmann, A., and Beaufort, L.: Coccolithophore response to climate and surface hydrography in Santa Barbara Basin, California, AD 1917-2004, Biogeosciences, 6, 2025-2039, doi:10.5194/bg-6-2025-2009, 2009.

Hagino, K., Okada, H., and Matsuoka, H.: Coccolithophore assemblages and morphotypes of Emiliania huxleyi in the boundary zone between the cold Oyashio and warm Kuroshio currents off the coast of Japan, Mar. Micropaleontol., 55, 19-47, 2005.

Hagino, K., Bendif, E. M., Young, J. R., Kogame, K., Probert, I., Takano, Y., Horiguchi, T., de Vargas, C., and Okada, H.: New evidence for morphological and genetic variation in the cosmopolotan coccolithophore Emiliania huxleyi (Prymnesiophyceae) from the COX1b-ATP4 GENES1, J. Phycol., 47, 11641176, doi:10.1111/j.1529-8817.2011.01053.x, 2011.

Hansen, B. and Østerhus, S.: North Atlantic-nordic seas exchanges, Prog. Oceanogr., 45, 109-208, 2000.

Henderiks, J., Winter, A., Elbrächter, M., Feistel, R., Plas, der, A., Nausch, G., and Barlow, R.: Environmental controls on Emiliania huxleyi morphotypes in the Benguela coastal upwelling system (SE Atlantic), Mar. Ecol.-Prog. Ser., 448, 51-66, doi:10.3354/meps09535, 2012.

Indermühle, A., Stocker, T. F., Joos, F., Fischer, H., Smith, J., Wahlen, M., DeCk, B., Mastroianni, D., Tschumi, J., and Blunier, T.: Holocene carbon-cycle dynamics based on $\mathrm{CO}_{2}$ trapped in ice at Taylor Dome, Antarctica, Nature, 398, 121-126, 1999.

IPCC (Intergovernmental Panel on Climate Change): Global Climate Projections, edited by: Solomon, S., Qin, D., Manning, M., Chen, Z., Marquis, M., Averyt, K. B., Tignor, M., and Miller, H. L. , Climate Change 2007: The Physical Science Basis, Contribution of Working Group I to the Fourth Assessment of the Intergovernmental Panel on Climate Change, Cambridge and New York: Cambridge University, 747-845, 2007.

Jansen, E., Raymo, M. E., Blum, P., Anderson, E. S., Austin, W. E. N., Baumann, K-H., Bout- Roumazeilles, V., Carter, S. J., Channell, J. E. T., Cullen, J. L., Flower, B., Higgins, S., Hodell, D. A., Hood, J. A., Hyun, S., Ikehara, M., King, T., Larter, R., Lehman, B., Locker, S., Mclntyre, K., McManus, J., Meng, L. B., O'Commell, S., Ortiz, J. D., Rack, F. R., Solheim, A., and Wei, W.: Proceedings of the ODP Initial Reports, 162, College Station, TX (Ocean Drilling Program), 1182 pp., 1996.

Jansen, E., Blum, P., and Party, S. S.: Gamma-ray attenuation measurements of bulk density using whole-core multi-sensing track on Hole, 162, 980B, doi:10.1594/PANGAEA.259998, 2005.

Kayano, K. and Shiraiwa, Y.: Physiological regulation of coccolith polysaccharide production by phosphate availability in the coccolithophorid Emiliania huxleyi, Plant Cell Physiol., 50, 15221531, doi:10.1093/pcp/pcp097, 2009.

Kissel, C., Kleiven, K., and Morin, X.: Les rapports de champagnes à la mer - MD 168/AMOCINT IMAGES XVII on board R/V Marion Dufresne, Inst. Polaire Fr., Plouzané, France, 1-104, 2009.

Klaas, C. and Archer, D. E.: Association of sinking organic matter with various types of mineral ballast in the deep sea: Implications for the rain ratio, Global Biogeochem. Cy., 16, 1116, doi:10.1029/2001GB001765, 2002.

Kleijne, A., Kroon, D., and Zevenboom, W.: Phytoplankton and foraminiferal frequencies in northern Indian Ocean and Red Sea surface waters, Neth. J. Sea Res., 24, 531-539, doi:10.1016/0077-7579(89)90131-2, 1989.
Klein, B. and Siedler, G.: On the Origin of the Azores Current, J. Geophys. Res., 94, 6159-6168, 1989.

Krug, S. A., Schulz, K. G., and Riebesell, U.: Effects of changes in carbonate chemistry speciation on Coccolithus braarudii: a discussion of coccolithophorid sensitivities, Biogeosciences, 8 , 771-777, doi:10.5194/bg-8-771-2011, 2011.

Langer, G., Geisen, M., Baumann, K.-H., Kläs, J., Riebesell, U., Thoms, S., and Young, J. R.: Species-specific responses of calcifying algae to changing seawater carbonate chemistry, Geochem. Geophy. Geosy., 7, Q09006, doi:10.1029/2005GC001227, 2006.

Langer, G., Gussone, N., Nehrke, G., Riebesell, U., Eisenhauer, A., and Thoms, S.: Calcium isotope fractionation during coccolith formation in Emiliania huxleyi: independence of growth and calcification rate, Geochem. Geophys. Geosys., 8, Q05007, doi:10.1029/2006GC001422, 2007.

Lee, K., Tong, L. T., Millero, F. J., Sabine, C. L., Dickson, A. G., Goyet, C., Park, G. H., Wan- ninkhof, R., Feely, R. A., and Key, R. M.: Global relationships of total alkalinity with salinity and temperature in surface waters of the world's oceans, Geophys. Res. Lett., 33, L19605, doi:10.1029/2006GL027207, 2006.

Lewis, E. and Wallace, D. W. R.: Program Developed for $\mathrm{CO}_{2}$ System Calculations, ORNL/CDIAC-105, Carbon Dioxide Information Analysis Center, Oak Ridge National Laboratory, US Department of Energy, Oak Ridge, Tennessee 37831-6290, USA, 1998.

Lohbeck, K. T., Riebesell, U., and Reusch, T. B. H.: Adaptive evolution of a key phytoplankton species to ocean acidification, Nat. Geosci., 5, 346-351, doi:10.1038/ngeo1441, 2012.

Lototskaya, A., Ziveri, P., Ganssen, G. M., and van Hinte, J. E.: Calcareous nannofloral response to Termination II at $45 \mathrm{~N}, 25 \mathrm{~W}$ (northeast Atlantic), Mar. Micropaleontol., 34, 47-70, 1998.

Marchal, O., Cacho, I., Stocker, T. F., Grimalt, J. O., Calvo, E., Martrat, B., Shackleton, N., Vautravers, M., Cortijo, E., van Kreveld, S., Andersson, C., Koç, N., Chapman, M., Sbaffi, L., Duplessy, J. C., Sarnthein, M., Turon, J. L., Duprat, J., and Jansen, E.: Apparent long-term cooling of the sea surface in the northeast Atlantic and Mediterranean during the Holocene, Quaternary Sci. Rev., 21, 455-483, 2002.

Medlin, L. K., Barker, G., Campbell, L., Green, J. C., Hayes, P. K., Marie, D., Wrieden, S., and Vaulot, D.: Genetic characterisation of Emiliania huxleyi (Haptophyta), J. Marine Syst., 9, 13-31, 1996.

Meier, K. J. S., Beaufort, L., Heussner, S., and Ziveri, P.: The role of ocean acidification in Emiliania huxleyi coccolith thinning in the Mediterranean Sea, Biogeosciences Discuss., 10, 19701-19730, doi:10.5194/bgd-10-19701-2013, 2014.

Müller, M. N., Antia, A. N. and LaRoche, J.: Influence of cell cycle phase on calcification in the coccolithophore Emiliania huxleyi, Limnol. Oceanogr., 53, 506-512, 2008.

Müller, M. N., Beaufort, L., Bernard, O., Pedrotti, M. L., Talec, A., Sciandra, A.: Influence of $\mathrm{CO}_{2}$ and nitrogen limitation on the coccolith volume of Emiliania huxleyi (Haptophyta), Biogeosciences 9, 4155-4167, doi:10.5194/bg-9-4155-2012, 2012.

Nielsen, J. E. Ø.: Variability at Ocean Weather Station M in the Norwegian Sea, ICES Mar. Sc., 219, 371-374, 2003.

Okada, H. and McIntyre, A.: Seasonal distribution of modern coccolithophores in the western North Atlantic Ocean, Mar. Biol., 54, 319-328, 1979. 
Okada, H. and Wells, P.: Late Quaternary nannofossil indicators of climate change in two deep-sea cores associated with the Leeuwin Current off Western Australia, Palaeogeogr. Palaeocl., 131, 413-432, 1997.

Oppo, D., McManus, J., and Cullen, J.: Evolution and demise of the last interglacial warmth in the subpolar North Atlantic, Quaternary Sci. Rev., 25, 3268-3277, doi:10.1016/j.quascirev.2006.07.006, 2006.

Paillard, D., Labeyrie, L., and Yiou, P.: Macintosh program performs time-series analysis, EOS, Transactions of the American Geophysical Union, USA, 77, 379 pp., 1996.

Ploug, H., Hvitfeldt Iversen, H., Koski, M., and Buitenhuis, E. T.: Production, oxygen respiration rates, and sinking velocity of copepod fecal pellets: direct measurements of ballasting by opal and calcite, Limnol. Oceanogr., 53, 469-476, 2008.

Pollard, R. T., Read, J. F., Holliday, N. P., and Leach, H.: Water masses and circulation pathways through the Iceland Basin during Vivaldi 1996, J. Geophys. Res, 109, C04004, doi:10.1029/2003JC002067, 2004.

Poulton, A. J., Young, J. R., Bates, N. R., Balch, W. M.: Biometry of detached Emiliania huxleyi coccoliths along the Patagonian Shelf, Marine Ecology Progress Series, 433, 1-17, doi:10.3354/meps09445, 2011.

Raven, J., Caldeira, K., Elderfield, H., Hoegh-Guldberg, O., Liss, P., Riebesell, U., Shepherd, J., Turley, C., and Watson, A.: Ocean acidification due to increasing atmospheric carbon dioxide, The Royal Society, Policy Document 12/05, 60 pp., 2005.

Read, J. F.: CONVEX-91: water masses and circulation of the Northeast Atlantic subpolar gyre, Prog. Oceanogr., 48, 461-510, 2001.

Read, B. A., Kegel, J., Klute, M. J., Kuo, A., Lefebvre, S. C., Maumus, F., Mayer, C., Miller, J., Monier, A., Salamov, A., Young, J., Aguilar, M., Claverie, J.-M., Frickenhaus, S., Gonzales, K., Herman, E. K., Lin, Y.-C., Napier, J., Ogata, H., Sarno, A. F., Shmutz, J., Schroeder, D., de Vargas, C., Verret, F., von Dassow, P., Valentin, K., Van de Peer, Y., Wheeler, G., Dacks, J. B., Delwiche, C. F., Dyhrman, S. T., Glöckner, G., John, U., Richards, T., Worden, A. Z., Zhang, X., and Grigoriev, I. V.: Pan genome of the phytoplankton Emiliania underpins its global distribution, Nature, 499, 209-213, doi:10.1038/nature12221, 2013.

Richter, T.: Sedimentary fluxes at the Mid-Atlantic Ridge: sediment sources, accumulation rates, and geochemical characterization, GEOMAR Rep. 73, GEOMAR Res. Cent. for Mar. Geosci., Christian Albrechts Univ., Kiel, Germany, 1998.

Rickaby, R., Bard, E., Sonzogni, C., Rostek, F., Beaufort, L., Barker, S., Rees, G., and Schrag, D. P.: Coccolith chemistry reveals secular variations in the global ocean carbon cycle?, Earth Planet. Sc. Lett., 253, 83-95, doi:10.1016/j.epsl.2006.10.016, 2007.

Riebesell, U., Zondervan, I., Rost, B. Ė., Tortell, P. D., Zeebe, R. E., and Morel, F. M. M.: Re- duced calcification of marine plankton in response to increased atmospheric $\mathrm{CO}_{2}$, Nature, 407, 364367, 2000.

Rios, A. F., Pérez, F. F., Álvarez, M., Mintrop, L., González-Dávila, M., Santana Casiano, J. M., Lefèvre, N., Watson, A. J.: Seasonal sea-surface carbon dioxide in the Azores area, Marine Chemistry, 96, 35-51, doi10.1016/j.marchem.2004.11.001, 2005.

Risebrobakken, B., Jansen, E., Andersson, C., Mjelde, E., and Hevrøy, K.: A high-resolution study of Holocene paleoclimatic and paleoceanographic changes in the Nordic Seas, Paleoceanography, 18, 1017, doi:10.1029/2002PA000764, 2003.

Rogerson, M., Rohling, E. J., Weaver, P., and Murray, J. W.: The Azores front since the last glacial maximum, Earth Planet. Sc. Lett., 222, 779-789, doi:10.1016/j.eps1.2004.03.039, 2004.

Satoh, M., Iwamoto, K., Suzuki, I., and Shiraiwa, Y.: Cold stress stimulates intracellular calcification by the coccolithophore, Emiliania huxleyi (Haptophyceae) under phosphate-deficient conditions, Mar. Biotechnol., 11, 327-333, 2009.

Schwab, C., Kinkel, H., Weinelt, M., and Repschläger, J.: Coccolithophore paleoproductivity and ecology response to deglacial and Holocene changes in the Azores Current System, Paleoceanography, 27, PA3210, doi:10.1029/2012PA002281, 2012.

Sigman, D. M. and Haug, G. H.: The Biological Pump in the Past, Treatise on Geochemistry, 6, 491-528, 2003.

Smith, H. E. K., Tyrrell, T., Charalampopoulou, A., Dumousseaud, C., Legge, O. J., Birchenough, S., Pettit, L. R., Garley, R., Hartman, S. E., Hartman, M. C., Sagoo, N., Daniels, C. J., Achterberg, E. P., and Hydes, D. J.: Predominance of heavily calcified coccolithophores at low $\mathrm{CaCO}_{3}$ saturation during winter in the Bay of Biscay, P. Natl. Acad. Sci. USA, 109, 8845-8849, doi:10.1073/pnas.1117508109, 2012.

Solignac, S., Grelaud, M., de Vernal, A., Giraudeau, J., Moros, M., McCave, I. N., and Hoogakker, B.: Reorganization of the upper ocean circulation in the mid-Holocene in the northeastern Atlantic, Can. J. Earth Sci., 45, 1417-1433, doi:10.1139/E08-061, 2008.

Stolz, K. and Baumann, K.-H.: Changes in palaeoceanography and palaeoecology during Marine Isotope Stage (MIS) 5 in the eastern North Atlantic (ODP Site 980) deduced from calcareous nannoplankton observations, Palaeogeography, Palaeoclimatology, Palaeoecology, 292, 295-305, doi:10.1016/j.palaeo.2010.04.002, 2010.

Takahashi, T. Sutherland, S. C., Sweeney, C., Poisson, A., Metzl, N., Tilbrook, B., Bates, N., Wanninkhof, R., Feely, R. A., Sabine, C., Olafsson, J., and Nojiri, Y.: Global sea-air $\mathrm{CO}_{2}$ flux based on climatological surface ocean $p \mathrm{CO}_{2}$, and seasonal biological temperature effects, Deep-Sea Res. Pt. II, 49, 1601-1622, 2002.

Tans, P. P. and Conway, T. J.: Monthly Atmospheric $\mathrm{CO}_{2}$ Mixing Ratios from the NOAA CMDL Carbon Cycle Cooperative Global Air Sampling Network, 1968-2002. In Trends: A Compendium of Data on Global Change. Carbon Dioxide Information Analysis Center, Oak Ridge National Laboratory, US Department of Energy, Oak Ridge, Tenn., USA, 2005.

Triantaphyllou, M., Dimiza, M., Krasakopoulou, E., Malinverno, E., Lianou, V., and Souvermezoglou, E.: Seasonal variation in Emiliania huxleyi coccolith morphology and calcification in the Aegean Sea (Eastern Mediterranean), Geobios, 43, 99-110, doi:10.1016/j.geobios.2009.09.002, 2010.

Van Kreveld, S., Knappertsbusch, M., Ottens, J., Ganssen, G. M., and Van Hinte, J. E.: Biogenic carbonate and ice-rafted debris (Heinrich layers) accumulation in deep-sea sediments from a Northeast Atlantic piston core, Mar. Geol., 131, 21-46, 1996.

Waelbroeck, C., Labeyrie, L., Michel, E., Duplessy, J., McManus, J., Lambeck, K., Balbon, E., and Labracherie, M.: Sea-level and deep water temperature changes derived from benthic foraminifera isotopic records, Quaternary Sci. Rev., 21, 295-305, 2002. 
Weaver, P. P. E. and Pujol, C.: History of the last deglaciation in the alboran sea (western Mediterranean) and adjacent north Atlantic as revealed by coccolith floras, Palaeogeogr. Palaeocl., 64, 3542, doi:10.1016/0031-0182(88)90140-X, 1988.

Westbroek, P., Brown, C. W., Bleijswijk, J., Brownlee, C., Brummer, G. J., Conte, M., Egge, J., Fernández, E., Jordan, R., Knappertsbusch, M., Stefels, J., Veldhuis, M., van der Wal, P., and Young, J.: A model system approach to biological climate forcing, The example of Emiliania huxleyi, Global Planet. Change, 8, 27-46, 1993.

Young, J. and Ziveri, P.: Calculation of coccolith volume and its use in calibration of carbonate flux estimates, Deep-Sea Res. Pt. II, 47, 1679-1700, 2000.

Young, J., Geisen, M., Cros, L., Kleijne, A., Sprengel, C., Probert, I., and Østergaard, J.: A guide to extant coccolithophore taxonomy, Journal of Nannoplankton Research, 1, 1-125, 2003.

Zeebe, R. E. and Wolf-Gladrow, D.: $\mathrm{CO}_{2}$ in Seawater: Equilibrium, Kinetics, Isotopes: Equilibrium, Kinetics, Isotopes, Elsevier Science, Amsterdam, 2001.

Zeebe, R. E.: History of Seawater Carbonate Chemistry, Atmospheric $\mathrm{CO}_{2}$ and Ocean Acidification, Annu. Rev. Earth Planet. Sci., 40, 141-165, 2012.
Ziveri, P. and Thunell, R.: Coccolithophore export production in Guaymas Basin, Gulf of California: response to climate forcing. Deep-Sea Res. Pt. II, 47, 2073-2100, 2000.

Ziveri, P., Baumann, K., Böckel, B., Bollmann, J., and Young, J.: Biogeography of selected Holocene coccoliths in the Atlantic Ocean, Coccolithophores - from Molecular Processes to Global Impact, Springer, Berlin, 403 pp., 2004.

Ziveri, P., de Bernardi, B., Baumann, K.-H., Stoll, H., and Mortyn, P.: Sinking of coccolith carbonate and potential contribution to organic carbon ballasting in the deep ocean, Deep-Sea Res. Pt. II, 54, 659-675, doi:10.1016/j.dsr2.2007.01.006, 2007.

Zondervan, I., Zeebe, E., Rost, B., Riebesell., U.: Decreasing marine biogenic calcification: A negative feedback on rising atmospheric $p \mathrm{CO}_{2}$, Global Biogeochem. Cy., 15, 507-516, 2001.

Zondervan, I., Rost, B., and Riebesell, U.: Effect of $\mathrm{CO}_{2}$ concentration on the PIC/POC ratio in the coccolithophore Emiliania huxleyi grown under light-limiting conditions and different daylengths, J. Exp. Mar. Biol. Ecol., 272, 55-70, 2002.

Zondervan, I.: The effect of light, macronutrients, trace metals and $\mathrm{CO}_{2}$ on the production of calcium carbonate and organic carbon in coccolithophores - A review, Deep-Sea Res. Pt. II, 54, 521537, 2007. 